\title{
A model of Fe speciation and biogeochemistry at the Tropical Eastern North Atlantic Time-Series Observatory site
}

\author{
Y. Ye, C. Völker, and D. A. Wolf-Gladrow \\ Alfred Wegener Institute for Polar and Marine Research, Bremerhaven, Germany \\ Received: 27 February 2009 - Published in Biogeosciences Discuss.: 17 April 2009 \\ Revised: 2 September 2009 - Accepted: 16 September 2009 - Published: 7 October 2009
}

\begin{abstract}
A one-dimensional model of Fe speciation and biogeochemistry, coupled with the General Ocean Turbulence Model (GOTM) and a NPZD-type ecosystem model, is applied for the Tropical Eastern North Atlantic Time-Series Observatory (TENATSO) site. Among diverse processes affecting Fe speciation, this study is focusing on investigating the role of dust particles in removing dissolved iron (DFe) by a more complex description of particle aggregation and sinking, and explaining the abundance of organic Fe-binding ligands by modelling their origin and fate.

The vertical distribution of different particle classes in the model shows high sensitivity to changing aggregation rates. Using the aggregation rates from the sensitivity study in this work, modelled particle fluxes are close to observations, with dust particles dominating near the surface and aggregates deeper in the water column. POC export at $1000 \mathrm{~m}$ is a little higher than regional sediment trap measurements, suggesting further improvement of modelling particle aggregation, sinking or remineralisation.

Modelled strong ligands have a high abundance near the surface and decline rapidly below the deep chlorophyll maximum, showing qualitative similarity to observations. Without production of strong ligands, phytoplankton concentration falls to 0 within the first 2 years in the model integration, caused by strong Fe-limitation. A nudging of total weak ligands towards a constant value is required for reproducing the observed nutrient-like profiles, assuming a decay time of 7 years for weak ligands. This indicates that weak ligands have a longer decay time and therefore cannot be modelled adequately in a one-dimensional model.

The modelled DFe profile is strongly influenced by particle concentration and vertical distribution, because the most important removal of DFe in deeper waters is colloid for-
\end{abstract}

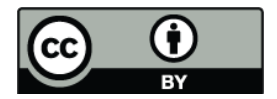

Correspondence to: $\mathrm{Y}$. Ye (ying.ye@awi.de) mation and aggregation. Redissolution of particulate iron is required to reproduce an observed DFe profile at TENATSO site. Assuming colloidal iron is mainly composed of inorganic colloids, the modelled colloidal to soluble iron ratio is lower that observations, indicating the importance of organic colloids.

\section{Introduction}

Iron is an essential micro-nutrient for marine phytoplankton. Its low availability in the upper ocean has been made responsible for the high-nitrate low-chlorophyll (HNLC) conditions in the Southern Ocean, the equatorial Pacific and the subpolar North Pacific (Boyd et al., 2007). It has been hypothesised that iron could also indirectly affect primary production in oligotrophic regions by limiting nitrogen-fixation (Mills et al., 2004.; Falkowski, 1997).

The solubility of iron is low under oxic conditions. Iron exists in seawater in different physical and chemical forms, e.g. inorganic soluble ferric and ferrous iron, organically complexed iron, colloidal and particulate iron. Some of these forms can be utilised by phytoplankton (Maldonado and Price, 1999; Hutchins et al., 1999) and transformed into organic particulate iron. Dissolved iron can be transported into the particulate pool also by scavenging onto particles (Balistieri et al., 1981), binding on cell surfaces (Hutchins et al., 2002; Tovar-Sanchez et al., 2003) and colloidal aggregation (Wells and Goldberg, 1993; Johnson et al., 1994; Wen et al., 1997), thereby becoming unavailable for biological uptake. Thus, iron bioavailability and residence time are controlled by its speciation and removal from the upper water layers.

Dust deposition, an important natural iron source for marine systems away from the continental shelf, is spatially and temporally variable and affected by climate change (Mahowald et al., 2003; Jickells et al., 2005). How it affects

Published by Copernicus Publications on behalf of the European Geosciences Union. 
marine productivity and thus the carbon cycle depends on the processes influencing $\mathrm{Fe}$ speciation and bioavailability. Recent studies enhanced our knowledge on many reactions in $\mathrm{Fe}$ speciation and factors influencing them. To provide a better understanding of the interaction of individual processes and the response of ecosystems to varying iron speciation, several numerical models focusing on different questions or regions have been developed: global models of iron cycling primarily aimed at reproducing the removal of iron by scavenging in the deep ocean (Parekh et al., 2004) or the characteristics of regional features under iron limitation (Aumont et al., 2003); process-based models have been refined for coastal waters by Rose and Waite (2003a), for the upper ocean at the Bermuda Atlantic Time-series Study (BATS) site by Weber et al. $(2005,2007)$ and for understanding the influence of light and temperature on the marine iron cycle (Tagliabue et al., 2009).

Weber et al. (2007) coupled a one-dimensional model of iron speciation and biogeochemistry with the General Ocean Turbulence Model (GOTM) and a NPZD-type (Nitrogen, Phytoplankton, Zooplankton and Detritus) ecosystem model. Our model is based on the model by Weber et al. (2007) and has been adapted and extended for the specific questions in this study:

1. High dust deposition brings not only considerable input of iron into surface waters but also fine inorganic particles for particle aggregation and Fe scavenging. What are the characteristics of the particle distribution in seawater? And how do they influence DFe removal and thus its bioavailability?

2. Fe speciation and concentration is largely regulated by the abundance of organic Fe-binding ligands. 99\% of dissolved $\mathrm{Fe}$ is organically complexed (Gledhill and van den Berg, 1994; van den Berg, 1995; Rue and Bruland, 1995). Studies in the last two decades have identified a number of different marine Fe-binding ligands and their vertical distribution are also measured in some regions (van den Berg, 1995; Rue and Bruland, 1995; Witter and Luther III, 1998; Witter et al., 2000; Boye et al., 2001, 2006; Cullen et al., 2006; Gerringa et al., 2006, 2008.). Sources and fate of these organic ligands are still largely unknown, although siderophore-like compounds are found to be produced by various marine bacteria and cyanobacteria and have similar conditional stability constants as the strong Fe-binding ligands occurring in natural seawater (Hunter and Boyd, 2007). Can the existing hypotheses on the origin and fate of organic ligands explain the observed ligand vertical distribution and organic complexation of iron?

Focusing on these two questions, we extended the model by Weber et al. (2007) by a more complex description of particle aggregation and sinking and by including organic ligand dynamics with sources and sinks (instead of prescribing lig- ands concentrations). We applied the model to simulate the cycling of iron at the Tropical Eastern North Atlantic TimeSeries Observatory (TENATSO) site $\left(17.4^{\circ} \mathrm{N}, 24.5^{\circ} \mathrm{W}\right)$, a new time-series station north of the Cape Verde Islands. The TENATSO site provides ideal conditions for investigation of dust deposition on Fe speciation and bioavailability in the upper ocean, because it is strongly influenced by Saharan dust events and its mixed layer depth has very low seasonal variability. Given that observations on Fe biogeochemistry are still sparse and that regular sampling at TENATSO has only recently begun, the main aim of this study is not the quantitative reproduction of the reality at TENATSO but the qualitative understanding of processes.

\section{Model description}

Our model consists of a physical, biological, and chemical model coupled in a one-dimensional vertical water column representing the upper $1000 \mathrm{~m}$ water depth. Horizontal gradients are assumed to be small and are thus neglected. The water column is divided into 100 layers. Layer spacing is given by $h_{n}=H \cdot(\tanh (2 n / N)-\tanh (2(n-1) / N)) / \tanh (2)$ where $H$ is the depth of the water column, $N$ is the number of layers, and $n=1$ is the lowermost layer, while $n=N$ is the surface layer. This results in a surface layer thickness of $1.5 \mathrm{~m}$ and 33 layers within the upper $100 \mathrm{~m}$.

The model is integrated forward in time until deep-ocean concentration profiles become cyclostationary, using a repeated atmospheric forcing from the 1 January 1990 to 31 December 1993. Due to the slow equilibration of deep dissolved iron and ligand profiles, the total integration time is 30 years. After this spin-up period the model is integrated over five more years for analysis, using forcing from 1 January 1990 to 31 December 1994. The time-step of the model is $1200 \mathrm{~s}$ and the biochemical variables are integrated forward in time using a modified Patankar scheme (Burchard et al., 2005) which is positive, conservative, and able to solve accurately systems that contain reactions with time-scales much shorter than the model time-step, such as photochemical reactions (see Sect. 2.4 Chemical model).

\subsection{Physical model}

The physical model is the General Ocean Turbulence Model (GOTM, Umlauf and Burchard, 2005, http://www.gotm. net/), which provides the vertical mixing and advection for given forcing by wind, heat and freshwater fluxes at the surface. The model configuration is based on the configuration by Weber et al. (2007), and has been adapted for the TENATSO site by forcing the model with daily fluxes derived from the ERA40 atmospheric reanalysis (Uppala et al., 2005) for the TENATSO site, and using a $k-\epsilon$ turbulence closure, with a minimum turbulent kinetic energy (TKE) value of $10^{-5} \mathrm{~m}^{2} \mathrm{~s}^{-2}$ to account for double diffusion. A 
third-order scheme with flux limiter (Burchard and Umlauf, 2005) is used for vertical advection and sinking of biogeochemical variables.

\subsection{Biological model}

The biological part of our model is a nitrogen-based ecosystem model developed originally by Schartau and Oschlies $(2003 \mathrm{a}, \mathrm{b})$. Its four compartments are nitrogen $(N)$, phytoplankton $(P)$, zooplankton $(Z)$, and detritus $(D)$. The processes and fluxes between them are mostly described in the same way as in Weber et al. (2007). We use the parameter values optimised for the North Atlantic by Schartau and Oschlies (2003a,b) (Table 1) which are also used successfully in the model for the European Station for Time-Series in the Ocean Canary Islands (ESTOC) station by Zielinski et al. (2002). A large set of sensitivity studies have been conducted to examine the effect of varying parameter values on primary and export production and the results are shown in the appendix (Appendix B, Table B1).

In Weber et al. (2007), the coupling between the ecosystem model and the chemical model is mediated by: 1) iron uptake by phytoplankton, 2) iron release during remineralisation, 3) scavenging of iron by detritus, and 4) the influence of phytoplankton on photochemical reactions through its influence on the attenuation of light. Our model contains additional interactions between biology and iron chemistry: 1) the bioavailability of iron controls the active production of ligands (Eq. A12 and Eq. A14), and 2) the organic complexation of iron is further affected by the release of ligands during remineralisation, and the biological and photochemical degradation of ligands (Eqs. A12, A13, A18 and Eq. A19); 3 ) furthermore, the formation of aggregates, and by that the vertical flux of adsorbed iron, is influenced by the amount of particulate organic matter (Eqs. A9-A11, Eqs. A22-A24).

Phytoplankton growth rate in our model depends on light, temperature, and nutrient supply. As in Weber et al. (2007), the uptake of iron by phytoplankton follows a MichaelisMenten dependency on the concentration of organically complexed dissolved iron, assuming that the latter is bioavailable (Maldonado and Price, 1999). The growth limitation of phytoplankton by iron is then calculated from its internal Fe:Nquota $Q_{\mathrm{Fe}}$ according to

$f_{\mathrm{Fe}}=\frac{Q_{\mathrm{Fe}}-Q_{\mathrm{Fe}}^{\min }}{Q_{\mathrm{Fe}}}$

where $Q_{\mathrm{Fe}}^{\min }$ is a minimal cellular Fe quota. The actual growth rate is then calculated as the product of a light and temperature dependent maximal growth rate with the smaller of $f_{\mathrm{Fe}}$ and $f_{\mathrm{N}}$, a Michaelis-Menten term in dissolved inorganic nitrogen:

$f_{\mathrm{N}}=\frac{N}{N+K_{\mathrm{N}}}$

where $K_{\mathrm{N}}$ is a half-saturation constant for dissolved inorganic nitrogen.

\subsection{Particle classes and aggregation}

The most important loss of DFe in deep waters is adsorption onto sinking particles (Balistieri et al., 1981; Honjo et al., 1982; Wen et al., 1997). Therefore, the vertical particle distribution and flux play a key role in determining the vertical profile of $\mathrm{Fe}$ and its deep-ocean residence time.

Sinking fluxes in the interior of the ocean are often dominated by larger aggregates (called "marine snow", if visible with the naked eye) and fecal pellets (e.g. Ratmeyer et al., 1999). These aggregates may contain dust (lithogenic) particles. On the other hand, fine particles dominate in Saharan dust deposition (Guieu et al., 2002; Heinold et al., 2007; Chiapello et al., 1997). Chiapello et al. (1997) reported a median size of $1.8 \mu \mathrm{m}$ for dust particles collected on Sal Island.

In the model we consider three size categories:

1. fine terrigenous material deposited by Saharan dust events with a mean size of around $2 \mu \mathrm{m}$ (B) and a sinking velocity of $1 \mathrm{~m} \mathrm{~d}^{-1}$;

2. small detritus and small aggregates with a typical size of $10 \mu \mathrm{m}$ and a sinking velocity of $5 \mathrm{~m} \mathrm{~d}^{-1}$;

3. large detritus and large aggregates with a typical size of $50 \mu \mathrm{m}$ and a sinking velocity of $50 \mathrm{~m} \mathrm{~d}^{-1}$.

Both small and large aggregates contain a biogenic and a lithogenic part. In the model equations (Appendix A), we use the symbols $D_{S}$ and $D_{L}$ for their organic part, and $A_{S}$ and $A_{L}$ for their inorganic part. The sinking velocity for fine dust particles and for small aggregates has been estimated from Stokes' law; for the larger aggregates it is close to estimates by Smayda (1970); Asper et al. (1992); Asper and Smith (2003); Kriest (2002). We neglect the impact of minerals on the sinking of organic particles (Armstrong et al., 2002; Francois et al., 2002; Hamm, 2002; Klaas and Archer, 2002) or vice versa (Passow, 2004) through fragmentation, influences on sinking velocity or on degradation rates.

Besides sinking, small suspended particles are removed by aggregation which transforms them into larger and more rapidly sinking particles (McCave, 1984; Jackson and Burd, 1998). Analytical expressions exist for so-called coagulation kernels which describe the probability of encounter between differently-sized particles through the mechanisms of Brownian motion, turbulent shear, and differential settling (e.g. Burd and Jackson, 2009). We used these analytical expressions to estimate aggregation rates for our three particle classes, and the relative role that the three mechanisms of encounter play in aggregation dynamics (Table 2). Small particles coagulate mainly by turbulent shear, whereas differential sedimentation dominates the coagulation between small and large particles. Brownian motion plays only a negligible role.

The different stickiness of particles was ignored in the calculation of coagulation kernels, assuming it to be one. This is certainly an overestimate, especially for dust particles. Furthermore, the coagulation kernels are strictly valid only if one 
Table 1. Parameters in the biological model. Source of parameter values are shown as footnotes; other parameters are optimised for the North Atlantic by Schartau and Oschlies (2003a,b).

\begin{tabular}{|c|c|c|c|}
\hline Parameters & Symbol & Unit & Value \\
\hline maximum growth rate of phytoplankton & $\mu_{\max }$ & $d^{-1}$ & 0.27 \\
\hline phytoplankton mortality & $\gamma_{p}$ & $d^{-1}$ & 0.04 \\
\hline initial slope P-I curve & $\alpha$ & $\mathrm{m}^{2} \mathrm{~W}^{-1} \mathrm{~d}^{-1}$ & 0.256 \\
\hline nitrate half-saturation constant & $K_{\mathrm{N}}$ & $\mu \mathrm{mol} \mathrm{L}-1$ & 0.7 \\
\hline iron half-saturation constant & $K_{\mathrm{Fe}}$ & $\mathrm{nmol} \mathrm{L}^{-1}$ & 0.2 \\
\hline phytoplankton aggregation rate & $\gamma_{p^{2}}$ & $\left(\mu \mathrm{mol} \mathrm{L}{ }^{-1}\right)^{-1} \mathrm{~d}^{-1}$ & 0.025 \\
\hline maximum grazing rate & $g_{\max }$ & $d^{-1}$ & 1.575 \\
\hline prey capture rate & $\epsilon$ & $\left(\mu \mathrm{mol} \mathrm{L}^{-1}\right)^{-1} \mathrm{~d}^{-1}$ & 1.6 \\
\hline assimilation efficiency & $\gamma_{z a}$ & - & 0.925 \\
\hline excretion & $\gamma_{z b}$ & $d^{-1}$ & 0.01 \\
\hline quadratic mortality of zooplankton & $\gamma_{z^{2}}$ & 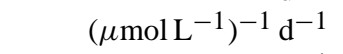 & 0.34 \\
\hline detritus remineralisation & $\gamma_{d}$ & $d^{-1}$ & 0.048 \\
\hline sinking velocity of dust particles & $w_{d}$ & $\mathrm{md}^{-1}$ & $1^{\mathrm{a}}$ \\
\hline sinking velocity of small particles & $w_{s}$ & $\mathrm{md}^{-1}$ & $5^{\mathrm{a}}$ \\
\hline sinking velocity of aggregates & $w_{l}$ & $\mathrm{md}^{-1}$ & $50^{\mathrm{b}}$ \\
\hline coeff. for temp. func. & $C_{\text {ref }}$ & - & 1.066 \\
\hline PAR:short-wave irradiance ratio & $f_{P A R}$ & - & 0.43 \\
\hline attenuation due to chlorophyll & $\kappa$ & $\mathrm{m}^{2}(\mathrm{mmol} \mathrm{N})^{-1}$ & 0.03 \\
\hline maximum $\mathrm{Fe}: \mathrm{N}$ ratio in organic matter & $Q_{\mathrm{Fe}}^{\max }$ & $\operatorname{nmol~L}{ }^{-1}\left(\mu \mathrm{mol} \mathrm{L}^{-1}\right)^{-1}$ & $0.033^{\mathrm{c}}$ \\
\hline minimum Fe: $\mathrm{N}$ ratio in organic matter & $Q_{\mathrm{Fe}}^{\min }$ & $\mathrm{nmol} \mathrm{L}{ }^{-1}\left(\mu \mathrm{mol} \mathrm{L}^{-1}\right)^{-1}$ & $6.6 \times 10^{-3^{\mathrm{a}}}$ \\
\hline mass: $\mathrm{N}$ ratio in organic matter & $r_{\mathrm{m}: \mathrm{N}}$ & $\mathrm{g} \mathrm{mol}^{-1}$ & $159^{d}$ \\
\hline
\end{tabular}

a Estimated from Stokes' Law, see Sect. 2.3.

b Estimates by Smayda (1970); Asper et al. (1992); Asper and Smith (2003); Kriest (2002).

c Sunda and Huntsman (1995).

${ }^{\mathrm{d}}$ Calculated with Redfield C:N ratio and the assumption that $1 \mathrm{~g} \mathrm{C}$ corresponds $2 \mathrm{~g}$ mass.

Table 2. Aggregation rates $\left(\mathrm{kg}^{-1} \mathrm{~L} \mathrm{~s}^{-1}\right)$ estimated from coagulation kernels in Burd and Jackson (2009) for different combinations of particle classes. Conversion from coagulation rates (in $\mathrm{L} \mathrm{s}^{-1}$ ) was done by dividing through the weight of the larger particle, resulting in a aggregation loss rate for the smaller particle concentration per concentration of the larger particle.

\begin{tabular}{lrrr}
\hline Particles & Brownian motion & Turbulent shear & Differential settling \\
\hline dust\& small particles* & 0.8 & $4 \times 10^{3}$ & $1.0 \times 10^{4}$ \\
between small particles* & 0.3 & $2.6 \times 10^{4}$ & 0 \\
small\& large particles* & $2.1 \times 10^{-2}$ & $8.8 \times 10^{3}$ & $3.3 \times 10^{4}$ \\
dust\& large particles* & 0.1 & $3.6 \times 10^{3}$ & $2.8 \times 10^{4}$ \\
\hline
\end{tabular}

* small particles include both small detritus and small aggregates, large particles include both large detritus and large aggregates.

represents the size distribution by a sufficiently fine resolved size distribution. Empirical estimates of aggregation rates for models with low size resolution, such as ours, are lower, sometimes orders of magnitude, than those determined from aggregation kernels (Ruiz et al., 2002). Ruiz et al. (2002) used mesocosms data to estimate an aggregation rate between two size classes approximately corresponding to our small and large aggregates of $15.8 \mathrm{~kg}^{-1} \mathrm{~L} \mathrm{~s}^{-1}$, while e.g. Gruber et al. (2006) used a value of $3.6 \times 10^{-5} \mathrm{~kg}^{-1} \mathrm{~L} \mathrm{~s}^{-1}$ for the formation of large aggregates through aggregation between small-sized particles.
We therefore ran the model with a range of different aggregation rates (Table 3) and compared the resulting particle distribution and flux with observations (Ratmeyer et al., 1999; Emery and Honjo, 1979; Bory et al., 2001). Based on this sensitivity study, we choose the constant from Ruiz et al. (2002) for the aggregation between small and large aggregates $\left(k_{\mathrm{coag} 3}\right)$ and calculated constants for other aggregation processes using the ratios between the different rates from Table 2 . 
Table 3. List of sensitivity model runs with respect to aggregation rates. Shown in the table is only the aggregation rate between small and large aggregates $k_{\mathrm{coag} 3}$; the other aggregation rates were varied in parallel, keeping the ratio between the different aggregation rates at the ratios from Table 2. Other columns show some integral characteristics of the runs, averaged over the last 5 years of the run: $F_{\text {org }}$ is the sinking flux of organic carbon at $100 \mathrm{~m}$ and $1000 \mathrm{~m}$ depth (in brackets). $C_{B}, C_{A S}$ and $C_{A L}$ are the fractions of inorganic particulates that are contained in dust particles, small and large aggregates, respectively, at the surface and at $1000 \mathrm{~m}$ (in brackets). Run R corresponds to the aggregation rate estimated by Ruiz et al. (2002), run A4 to the values from Table 2.

\begin{tabular}{lrrrrr}
\hline Name & $\begin{array}{r}k_{\mathrm{coag} 3} \\
\left(\mathrm{~kg}^{-1} \mathrm{~L} \mathrm{~s}^{-1}\right)\end{array}$ & $\begin{array}{r}F_{\text {org }} \\
\left(\mathrm{mg} \mathrm{C} \mathrm{m}^{-2} \mathrm{~d}^{-1}\right)\end{array}$ & $\begin{array}{r}C_{B} \\
(\%)\end{array}$ & $\begin{array}{r}C_{A S} \\
(\%)\end{array}$ & $\begin{array}{r}C_{A L} \\
(\%)\end{array}$ \\
\hline A0 & 0.0 & $91.8(17.0)$ & $100(100)$ & $0(0)$ & $0(0)$ \\
A1 & 1.5 & $92.0(17.0)$ & $100(99.1)$ & $0(0.4)$ & $0(0.4)$ \\
R & 15 & $81.7(15.1)$ & $99.7(74.3)$ & $0.3(14.6)$ & $0(11.1)$ \\
A2 & 150 & $93.1(18.2)$ & $96.2(0)$ & $3.5(1)$ & $0.3(99)$ \\
A3 & 1500 & $91.7(18.7)$ & $87.8(0)$ & $9.1(0)$ & $3.1(100)$ \\
A4 & 33000 & $92.5(18.9)$ & $63.8(0)$ & $5.8(0)$ & $30.3(100)$ \\
\hline
\end{tabular}

\subsection{Chemical model}

\subsubsection{Fe speciation}

Five iron species are distinguished in the chemical part of the model: 1) soluble (truly dissolved) inorganic ferric iron $\mathrm{Fe}(\mathrm{III})$ ', which includes all hydrolysed species in the form of $\mathrm{Fe}(\mathrm{OH})_{\mathrm{n}}^{3-\mathrm{n}} ; 2$ 2) soluble inorganic ferrous iron $\left.\mathrm{Fe}(\mathrm{II})^{\prime} ; 3\right)$ organically complexed iron $\mathrm{Fe}_{\text {lig }}$ which is further subdivided into complexes with strong $\left(\mathrm{FeL}_{\text {str }}\right)$ and weak ligands $\left(\mathrm{FeL}_{\mathrm{we}}\right)$; 4) colloidal iron $\mathrm{Fe}_{\mathrm{col}}$; and 5) iron bound to the surface of sinking particles $\mathrm{Fe}_{\mathrm{p}}$. In field work, soluble iron $\left(\mathrm{Fe}_{\mathrm{sol}}\right)$ is often defined by a filter cutoff of $0.02 \mu \mathrm{m}$ which corresponds to the sum of $\mathrm{Fe}(\mathrm{III})$ ', $\mathrm{Fe}(\mathrm{II})^{\prime}$ and $\mathrm{Fe}_{\mathrm{lig}}$ in our model; colloidal iron has the size between $0.02-0.4 \mu \mathrm{m}$ and particulate iron is $>0.4 \mu \mathrm{m}$. Dissolved iron (DFe) consists of soluble and colloidal iron and is the form of iron most often measured. To represent the kinetics of photochemical reactions, we also model the concentrations of $\mathrm{H}_{2} \mathrm{O}_{2}$ and $\mathrm{O}_{2}^{-}$.

The following processes converting iron between different species are included in our model (Fig. 1): 1) photoreduction of different ferric forms: the direct photo-reduction of $\mathrm{Fe}$ (III)', organically complexed iron, colloidal and particulate iron; and the indirect photo-reduction of $\mathrm{Fe}(\mathrm{III})$ ' by photoreduced superoxide; 2) oxidation of Fe(II)' by oxygen, superoxide and hydrogen peroxide; 3) complex formation and dissociation; 4) direct scavenging of $\mathrm{Fe}(\mathrm{III})$ ' onto sinking particles; 5) colloid formation and redissolution; 6) colloidal aggregation and redissolution of particulate iron. Most of the rate laws and constants are adopted from Weber et al. (2005) and the results of sensitivity studies in Weber et al. (2007). Parameter values and references are shown in Table 4.

Model results by Parekh et al. (2004) and Weber et al. (2007) show that it is necessary to introduce a pathway from particulate to dissolved iron in order to reproduce the relatively constant concentration of DFe in deep-water. The vertical distributions of another particle-reactive element, Th, also seem to require a desorptive pathway to explain con-

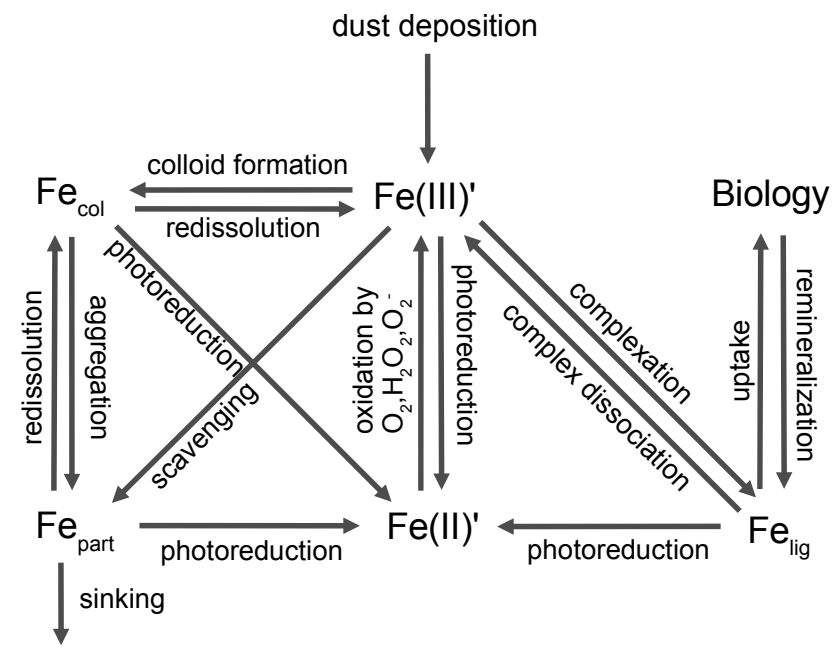

Fig. 1. Schematic representation of processes involved in the iron cycle in the model.

tinuous increases in depth of both particulate and dissolved fractions (Bacon and Anderson, 1982). The rates of this pathway for iron are still not well known. Here we choose the rate for colloid redissolution from Rose and Waite (2003b) $\left(k_{c d}=0.41 \mathrm{~d}^{-1}\right)$ and conducted a sensitivity study with respect to the rate of redissolution of particulate iron (see Sect. 3.4.2 Modelled DFe concentration).

Dust deposition fluxes simulated by Mahowald et al. (2003) are used for prescribing the surface flux of dust particles. The surface flux of iron is calculated with a constant content of iron and $1 \%$ solubility which is close to the mean value reported for the Saharan dust close to the source region (Spokes and Jickells, 1996; Baker et al., 2006a,b; Baker and Jickells, 2006). Fe content in dust varies from 3 to $7.6 \%$ (Wedepohl, 1995; Duce and Tindale, 1991; Spokes and Jickells, 1996; Desboeufs et al., 2001). A sensitivity study with 
Table 4. Parameters in the chemical model. By some parameters, the unit conversion results in a larger number of digits, e.g. $k_{\text {ox } 1}$, giving a false sense of accuracy.

\begin{tabular}{|c|c|c|c|}
\hline Parameters & Symbol & Unit & Value \\
\hline $\mathrm{Fe}(\mathrm{II})$ ' oxidation rate by $\mathrm{O}_{2}$ & $k_{\mathrm{OX} 1}$ & $\left(\mu \mathrm{mol} \mathrm{L} \mathrm{L}^{-1}\right)^{-1} \mathrm{~d}^{-1}$ & $0.864^{\mathrm{a}}$ \\
\hline oxygen concentration & {$\left[\mathrm{O}_{2}\right]$} & $\mu \mathrm{mol} \mathrm{L}^{-1}$ & $214^{\mathrm{b}}$ \\
\hline $\mathrm{Fe}(\mathrm{II})^{\prime}$ oxidation rate by $\mathrm{O}_{2}{ }^{-}$ & $k_{\mathrm{ox} 2}$ & $(\mathrm{nmol} \mathrm{L}-1)^{-1} \mathrm{~d}^{-1}$ & $864^{\mathrm{a}}$ \\
\hline $\mathrm{Fe}(\mathrm{II})^{\prime}$ oxidation rate by $\mathrm{H}_{2} \mathrm{O}_{2}$ & $k_{\mathrm{ox} 3}$ & $(\mathrm{nmol} \mathrm{L}-1)^{-1} \mathrm{~d}^{-1}$ & $6.24^{\mathrm{c}}$ \\
\hline reference irradiance & $i r_{\text {ref }}$ & $\mu \mathrm{Em}^{-3} \mathrm{~s}^{-1}$ & 1978 \\
\hline $\mathrm{Fe}(\mathrm{III})^{\prime}$ photoreduction rate & $k_{\mathrm{ph} 3}$ & $\mathrm{~d}^{-1}$ & $1.32^{\mathrm{d}}$ \\
\hline $\mathrm{Fe}_{\text {col }}$ photoreduction rate & $k_{\mathrm{ph} 1}$ & $\mathrm{~d}^{-1}$ & $1.32^{\mathrm{e}}$ \\
\hline $\mathrm{Fe}_{\mathrm{p}}$ photoreduction rate & $k_{\mathrm{ph} 4}$ & $\mathrm{~d}^{-1}$ & $20.2^{\mathrm{d}}$ \\
\hline FeL $_{\text {str }}$ photoreduction rate & $k_{\text {phls }}$ & $\mathrm{d}^{-1}$ & $0.38^{\mathrm{f}}$ \\
\hline $\mathrm{FeL}_{\mathrm{we}}$ photoreduction rate & $k_{\text {phlw }}$ & $\mathrm{d}^{-1}$ & $7.6^{\mathrm{g}}$ \\
\hline $\mathrm{Fe}(\mathrm{III})^{\prime}$ reduction rate by $\mathrm{O}_{2}^{-}$ & $k_{\text {red }}$ & 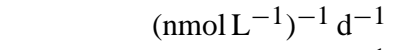 & $1.3 \times 10^{4 \mathrm{a}}$ \\
\hline $\mathrm{Fe}_{\mathrm{col}}$ formation rate & $k_{\mathrm{col}}$ & $\mathrm{d}^{-1}$ & $2.4^{\mathrm{d}}$ \\
\hline $\mathrm{Fe}_{\text {lig formation rate }}$ & $k_{\mathrm{fel}}$ & 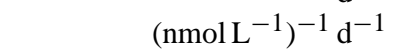 & $172.8^{\mathrm{h}}$ \\
\hline $\mathrm{FeL}_{\text {str }}$ conditional stability constant & $k_{1 \mathrm{sd}}$ & $\left(\mathrm{mol} \mathrm{L}^{-1}\right)^{-1}$ & $10^{12 \mathrm{i}}$ \\
\hline FeL $_{\text {we }}$ conditional stability constant & $k_{\text {lwd }}$ & $\left(\mathrm{mol} \mathrm{L}^{-1}\right)^{-1}$ & $10^{10.3 \mathrm{i}}$ \\
\hline $\mathrm{Fe}(\mathrm{III})$ ' scavenging rate & $k_{\text {sca }}$ & $\mathrm{kg}^{-1} \mathrm{Ld}^{-1}$ & $2500^{\mathrm{j}}$ \\
\hline $\mathrm{Fe}_{\text {col }}$ aggregation rate & $k_{a g}$ & $\mathrm{~kg}^{-1} \mathrm{Ld}^{-1}$ & $1.224 \times 10^{6^{\mathrm{k}}}$ \\
\hline $\mathrm{Fe}_{\text {col }}$ redissolution rate & $k_{c d}$ & $\mathrm{~d}^{-1}$ & $0.41^{1}$ \\
\hline $\mathrm{Fe}_{\mathrm{p}}$ redissolution rate & $k_{p d}$ & $\mathrm{~d}^{-1}$ & $0.015^{\mathrm{m}}$ \\
\hline $\mathrm{O}_{2}^{-}$dismutation rate & $k_{d m}$ & 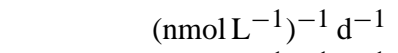 & $2.64^{\mathrm{a}}$ \\
\hline $\mathrm{O}_{2}^{-}$production rate & $S_{\mathrm{O}_{2}^{-}}$ & 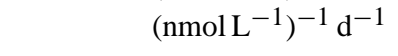 & $1037^{\mathrm{n}}$ \\
\hline $\mathrm{H}_{2} \mathrm{O}_{2}$ decay rate & $k_{\mathrm{dis}}^{2}$ & $d^{-1}$ & $0.24^{\mathrm{a}}$ \\
\hline solubility of atmospheric iron & $k_{\mathrm{Sol}}$ & $\%$ & $1^{\mathrm{o}}$ \\
\hline Total $\mathrm{Cu}$ concentration & {$\left[\mathrm{Cu}_{T}\right]$} & $\mathrm{nmol} \mathrm{L}-1$ & $1^{\mathrm{p}}$ \\
\hline $\mathrm{Cu}(\mathrm{I})$ oxidation rate by $\mathrm{O}_{2}^{-}$ & $k_{\text {cuox }}$ & 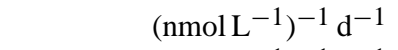 & $8.1 \times 10^{5^{\mathrm{a}}}$ \\
\hline $\mathrm{Cu}$ (II) reduction rate by $\mathrm{O}_{2}^{-}$ & $k_{\text {cured }}$ & $(\mathrm{nmol} \mathrm{L}-1)^{-1} \mathrm{~d}^{-1}$ & 182 \\
\hline ligand production rate by phytoplankton & $\gamma_{l p}$ & $\operatorname{nmol~L}{ }^{-1}\left(\mu \mathrm{mol} \mathrm{L}^{-1}\right)^{-1} \mathrm{~d}^{-1}$ & $0.5^{\mathrm{q}}$ \\
\hline ligand release rate from detritus & $\gamma_{l d}$ & $\operatorname{nmol~L} L^{-1}\left(\mu \mathrm{mol} \mathrm{L}^{-1}\right)^{-1} \mathrm{~d}^{-1}$ & $0.04^{\mathrm{r}}$ \\
\hline ligand remineralisation & $\gamma_{l s}$ & $d^{-1}$ & $0.038^{\mathrm{s}}$ \\
\hline ligand remineralisation & $\gamma_{l w}$ & $\mathrm{~d}^{-1}$ & $0.00038^{\mathrm{m}}$ \\
\hline coagulation rate & $k_{\text {coag } 1}$ & $\left(\mathrm{~kg} \mathrm{~L}^{-1}\right)^{-1} \mathrm{~s}^{-1}$ & $4.5^{\mathrm{t}}$ \\
\hline coagulation rate & $k_{\mathrm{coag} 2}$ & $\left(\mathrm{~kg} \mathrm{~L}^{-1}\right)^{-1} \mathrm{~s}^{-1}$ & $11^{\mathrm{t}}$ \\
\hline coagulation rate & $k_{\text {coag3 }}$ & $\left(\mathrm{kg} \mathrm{L}^{-1}\right)^{-1} \mathrm{~s}^{-1}$ & $15^{\mathrm{u}}$ \\
\hline coagulation rate & $k_{\text {coag} 4}$ & $\left(\mathrm{~kg} \mathrm{~L}^{-1}\right)^{-1} \mathrm{~s}^{-1}$ & $13^{\mathrm{t}}$ \\
\hline
\end{tabular}

${ }^{a}$ Voelker and Sedlak (1995); ${ }^{\mathrm{b}}$ estimated from the solubility of oxygen at $25^{\circ} \mathrm{C} ;{ }^{\mathrm{c}}$ Millero and Sotolongo (1989); ${ }^{\mathrm{d}}$ Johnson et al. (1994); e Barbeau and Moffett (2000); ${ }^{\mathrm{f}}$ estimated from Powell and Wilson-Finelli (2003); ${ }^{\mathrm{g}}$ calculated from $k_{\text {phls }}$ according to their ratio in Rose and Waite (2003c); ${ }^{\mathrm{h}}$ Hudson et al. (1992), found in the range of Witter and Luther III (1998); ${ }^{\mathrm{i}}$ Rue and Bruland (1995); ${ }^{\mathrm{j}}$ Sensitivity study of Weber et al. (2007); ${ }^{\mathrm{k}}$ Wen et al. (1997); ${ }^{1}$ Rose and Waite (2003b); ${ }^{\mathrm{m}}$ sensitivity study in this work; ${ }^{\mathrm{n}}$ in the range of 2 and $100 \mathrm{pM} \mathrm{s}{ }^{-1}$ (Micinski et al., 1993), cited in Voelker and Sedlak (1995); ${ }^{\circ}$ see Appendix B, Table B2; $\mathrm{p}$ van der Loeff et al. (1997); ${ }^{\mathrm{q}}$ estimated in this work; ${ }^{\mathrm{r}}$ estimated from Schlosser and Croot (2009); ${ }^{\mathrm{s}}$ Amon and Benner (1994); ${ }^{\mathrm{t}}$ calculated according to their ratio to $k_{\mathrm{coag} 3}$ (Table 2); ${ }^{\mathrm{u}}$ Ruiz et al. (2002).

respect to the product of iron content and solubility (see Appendix B, Table B2) resulted in choosing $3.5 \%$ for the calculation of surface iron flux.

\subsubsection{Organic ligands and complexation}

Some marine microorganisms, mostly heterotrophic bacteria and cyanobacteria, are reported to produce siderophores to facilitate Fe uptake (Trick, 1989; Reid et al., 1993; Wilhelm and Trick, 1994; Wilhelm et al., 1996; Granger and Price, 
1999; Martinez et al., 2000; Martinez and Haygood, 2001; Martinez et al., 2003; Barbeau et al., 2001; Macrellis et al., 2001). This production is widely supposed to be regulated by iron level (Reid et al., 1993; Wilhelm and Trick, 1994; Wilhelm et al., 1996; Macrellis et al., 2001). The conditional stability constant of siderophores is similar to that of the naturally occurring strong Fe-binding ligands in seawater (Rue and Bruland, 1995; Lewis et al., 1995; Macrellis et al., 2001) which predominate in the upper water column (Rue and Bruland, 1995, 1997). Weak ligands are more abundant deeper in the water column and have similar conditional stability constant as the porphyrin-type ligands which are supposed to be released as degradation products of cytochrome system (Boye et al., 2001).

To the best of our knowledge, this is the first model considering the sources and fate of organic Fe-binding ligands explicitly. Weber et al. (2007) assumed a fixed concentration of free Fe-binding organic ligands, in excess of DFe concentration. In our model, two types of ligands are introduced with different conditional stability constants: free strong ligands $\left(\mathrm{L}_{\mathrm{str}}\right)$ and weak ligands $\left(\mathrm{L}_{\mathrm{we}}\right)$, as well as two types of complexes, respectively: FeL $\mathrm{L}_{\text {str }}$ and $\mathrm{FeL}_{\mathrm{we}}$ (Fig. 2).

We assume a production of strong ligands by phytoplankton under Fe-limitation. The rate of siderophore production is not yet well known. We tested the sensitivity of phytoplankton growth to the rate of ligand production and found that phytoplankton growth decreases without the active production of ligands, because of strong Fe-limitation in surface waters. We estimated the maximal production rate $\left(\gamma_{l p}\right)$ by keeping the phytoplankton concentration close to the observations (see Sect. 3.2 Biological conditions). The ligand production rate is regulated by the internal Fe:N-quota of phytoplankton (Eq. A14). Weak ligands are released by decomposition of detritus. Schlosser and Croot (2009) used data from the Mauritanian upwelling zone to estimate a $\mathrm{PO}_{4}^{3-}$ :ligand ratio in the decomposition of organic matter. We use this estimate together with a Redfield P:N ratio to calculate the release rate $\left(\gamma_{l d}\right)$ of weak ligands in our model.

Another source of weak ligands in the model is photoreaction of the strong Fe-ligand complex $\left(\mathrm{FeL}_{\mathrm{str}}\right)$. Organic ligands are often photochemically reactive and the product of photolysis of strong ligands is reported to retain a lower ability to complex Fe(III)' (Barbeau et al., 2001, 2003; Powell and Wilson-Finelli, 2003). In our model, organic complexes with both strong and weak ligands are degraded by photolysis. We assume that ligands released by photolysis of Fe $\mathrm{L}_{\text {str }}$ have the same ability to form organic complexes as weak ligands, and ligands oxidised by photolysis of $\mathrm{FeL}_{\mathrm{we}}$ lose their binding ability completely. Photoreduction rate of $\mathrm{FeL}_{\mathrm{str}}\left(k_{\mathrm{phls}}\right)$ is estimated from the experimental data by Powell and Wilson-Finelli (2003) and that of $\mathrm{FeL}_{\mathrm{we}}$ is calculated according to Rose and Waite (2003c) in proportion to $k_{\text {phls }}$. Both of them are made proportional to light intensity in our model.

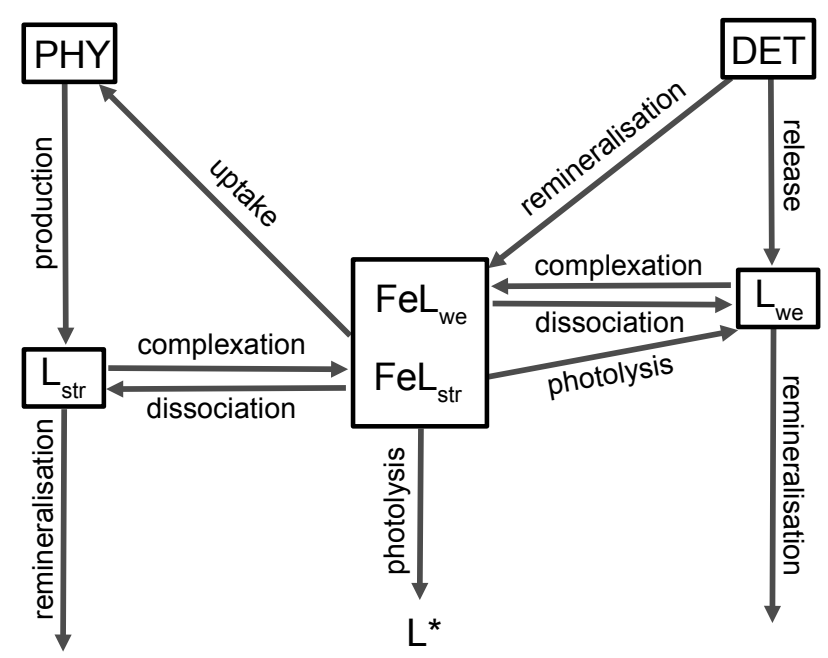

Fig. 2. Schematic representation of sources and fate of organic ligands in the model. $\mathrm{L}^{*}$ is the product of photolysis of $\mathrm{FeL}_{\mathrm{we}}$ which loses the ability to bind iron.

Measured ligand concentrations in the deep ocean show small variation with depth, indicating that ligands have a long decay time or a fraction of them is refractory (Hunter and Boyd, 2007). A major part of these ligands might be humic substances (Laglera and van den Berg, 2009), which are degraded very slowly compared to other DOM. We use the decay time of DOM from Amon and Benner (1994) (26 days) for remineralisation of strong ligands because of their relatively small molecular weight compared to weak ligands and their predominance in upper water column. A sensitivity study is conducted to estimate the decay time of weak ligands (see Sect. 3.4.1 Organic complexation).

Other processes controlling concentration of organic ligands are: organic complexation with $\mathrm{Fe}(\mathrm{III})$ ' and complex dissociation (Witter and Luther III, 1998) as well as uptake by phytoplankton (Hutchins et al., 1999; Maldonado and Price, 1999; Wang and Dei, 2001). In our model, phytoplankton take up all the forms of complexed iron with the same rate coefficient.

\section{Results and discussion}

\subsection{Physical conditions}

The annual cycle of the mixed layer depth in the model is primarily driven by seasonal changes in surface heat flux and wind stress. Averaged daily high temperatures in the subtropical climate at the TENATSO site range only from $25^{\circ} \mathrm{C}$ to $29^{\circ} \mathrm{C}$. The modelled thermal stratification is strong during the whole year and the mixed layer depth shows relatively low seasonal variability. The annual pattern of mixed layer depth is similar to the climatological estimate by De Boyer Montegut et al. (2004) (Fig. 3). 
A characteristic feature observed at the TENATSO site is the existence of a shallow layer of high-salinity water underneath the winter maximum mixed layer depth which originates from near the centre of the subtropical gyre at $30^{\circ} \mathrm{N}$ and spreads along isopycnals. Maintaining the effect of this lateral source of high-salinity water on density stratification in a one-dimensional model requires an additional unphysical forcing for salinity and temperature towards observations. We have used a weak uniform forcing proportional to modeldata difference with a time-scale of three months. Not surprisingly therefore, modelled temperature and salinity are in good agreement with observations. This unphysical forcing is weak enough to allow for a realistic high-frequency variability in mixed-layer depth.

\subsection{Biological conditions}

The modelled chlorophyll a concentration in surface waters is between 0.25 to $0.45 \mu \mathrm{g} \mathrm{L}^{-1}$ which is within the range of the observations at the TENATSO site or during cruises past the Cape Verde Islands. Between March and November, a deep chlorophyll maximum with values around $0.45 \mu \mathrm{g} \mathrm{L}^{-1}$ develops at the depth of the nutricline near $70 \mathrm{~m}$. However, the observed chlorophyll surface concentrations vary somewhat more strongly from 0.06 to $0.7 \mu \mathrm{g} \mathrm{L}^{-1}$ (Cruise data of POS 320/1, POS 332, Meteor 68/3, POS 348/2, Merian 20 April 2008, L. Cotrim da Cunha, personal communication, 2008 and I. Peeken, personal communication, 2009). One explanation for the lower than observed $\mathrm{Chl}$ variability in the model could be a fixed $\mathrm{Chl}: \mathrm{C}$ ratio $(0.01 \mathrm{mg} \mathrm{Chl}$ $\left.(\mathrm{mg} \mathrm{C})^{-1}\right)$ used for calculation of Chl concentration. Alternatively, we calculated $\mathrm{Chl}$ concentrations using the empirical Chl:C-ratio from Cloern et al. (1995) and obtained lower surface concentrations $\left(0.05-0.33 \mu \mathrm{g} \mathrm{L}^{-1}\right)$ and higher subsurface maximum (mean $0.9 \mu \mathrm{gL}^{-1}$ ). Figure 4 shows that the calculated $\mathrm{Chl}$ reproduces well the observed surface $\mathrm{Chl}$, whereas the subsurface maximum is higher than the observations. For better estimation of the $\mathrm{Chl}: \mathrm{C}$ ratio at TENATSO, phytoplankton community composition and different physiology need to be considered, resulting in a more complex ecosystem model. This is, however, out of the scope of our study.

Primary production in the model varies seasonally from $450 \mathrm{~m} \mathrm{C} \mathrm{m}^{-2}$ day $^{-1}$ in winter to $700 \mathrm{mg} \mathrm{C} \mathrm{m}^{-2}$ day $^{-1}$ during spring blooms. The annual average is approximately $620 \mathrm{mg} \mathrm{C} \mathrm{m}^{-2}$ day $^{-1}$. Morel et al. (1996) reported primary productivity for typical eutrophic, mesotrophic and oligotrophic regimes in the tropical northeast Atlantic (EUMELI program). Primary production at the mesotrophic station $\left(18.5^{\circ} \mathrm{N}, 21^{\circ} \mathrm{W}\right)$, the nearest station to TENATSO, is ca. $700 \mathrm{mg} \mathrm{C} \mathrm{m}^{-2} \mathrm{day}^{-1}$. This value is a little higher than our modelled mean primary production which can be explained by the more remote location of TENATSO from the Northwest African coast. Primary production estimated from MODIS data, using the algorithm by Behrenfeld and

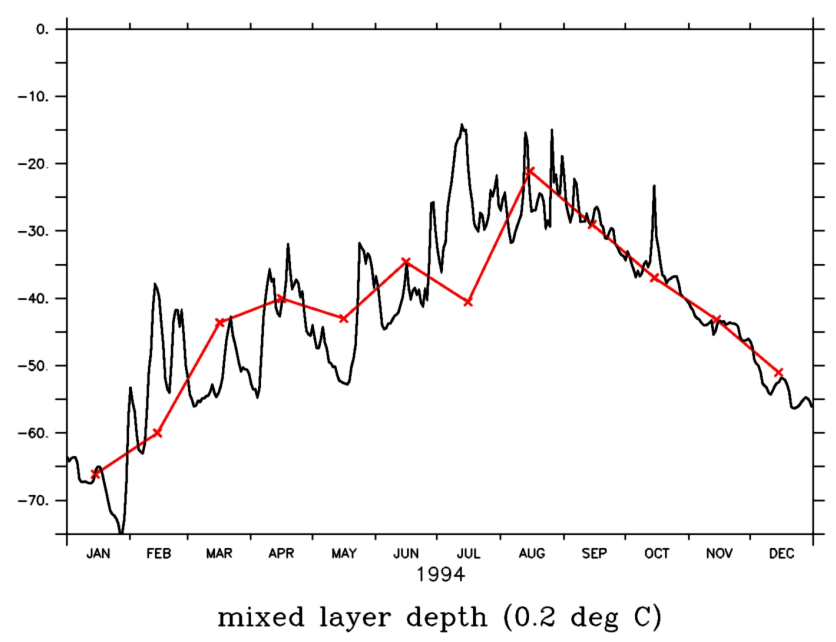

Fig. 3. Comparison of mixed layer depth (m) calculated with a $0.2^{\circ} \mathrm{C}$ criterion. Black: modelled mixed layer depth, red: climatological estimate by De Boyer Montegut et al. (2004).

Falkowski (1997) averages to $470 \mathrm{mg} \mathrm{C} \mathrm{m}^{-2} \mathrm{day}^{-1}$ for the $1^{\circ} \times 1^{\circ}$ square around the TENATSO station and the period from July 2002 to December 2007. Due to the relatively large variation between reported values, we are pleased with our value being within the variation.

Modelled export of POC at $100 \mathrm{~m}$ ranges from 40 to $120 \mathrm{mg} \mathrm{C} \mathrm{m}^{-2}$ day $^{-1}$ which is $6-20 \%$ of integrated primary production. This export to primary production ratio is in agreement with the typical open ocean values which range from 5 to 25\% (De La Rocha and Passow, 2007). The POC concentration at $100 \mathrm{~m}$ varies from 30 to $80 \mathrm{mg} \mathrm{m}^{-3}$ in the model, consistent with the observed $35-74 \mathrm{mg} \mathrm{m}^{-3}$ (Meteor 68/3, Atalánte cruise February 2008, I. Peeken, personal communication, 2009).

Phytoplankton growth in the model is limited by nitrogen rather than iron which is consistent with observations in North Atlantic (Graziano et al., 1996). The lowest value of the nitrogen limiting factor $f_{\mathrm{N}}$ (Eq. 2) is around 0.3 found in surface waters in summer and autumn when nitrogen is largely depleted after spring blooms. The iron limiting factor $f_{\mathrm{Fe}}$ (Eq. 1) varies between 0.65 and 0.80 . The strongest $\mathrm{Fe}$ limitation occurs immediately below the depth of the deep chlorophyll maximum where it is also stronger than $\mathrm{N}$ limitation. A feedback of phytoplankton to Fe limitation is provided by the production of strong organic ligands, primarily at the depth of the deep chlorophyll maximum. It is interesting to note that without production of strong organic ligands and restoring of weak ligands in the model, Fe limitation develops so fast that phytoplankton concentration falls to 0 within the first 2 years in the model integration. $\mathrm{N}$ limitation at TENATSO might be overestimated in our model, because we do not consider diazotrophs which are temporally abundant in this region (Tyrrell et al., 2003; Carpenter 

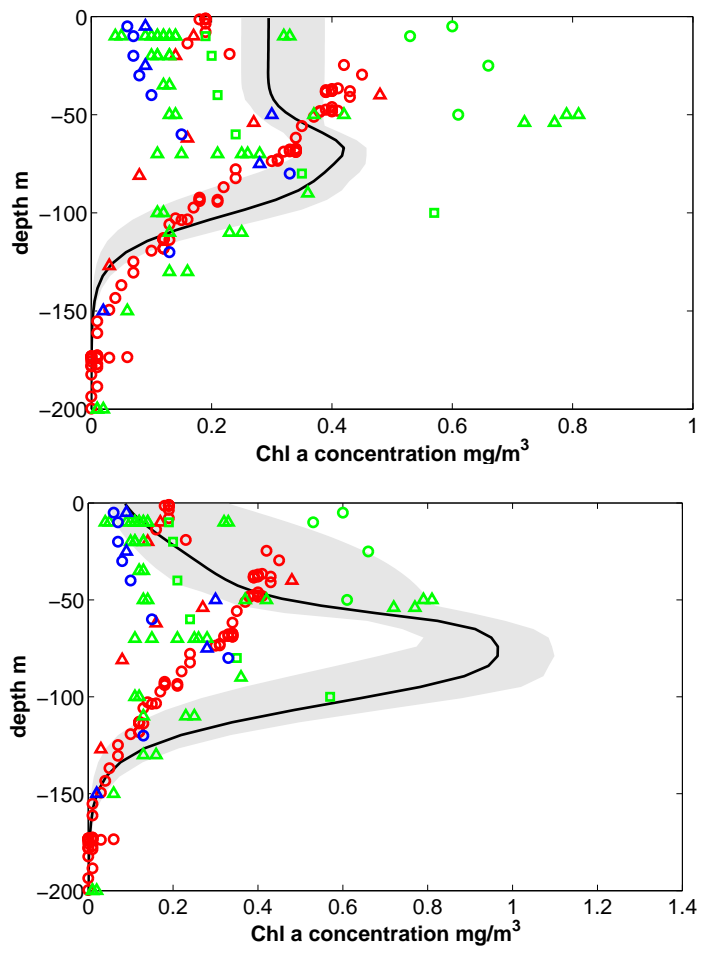

Fig. 4. Comparison of modelled Chl concentration with a fixed Chl:C ratio (upper panel) and with the empirical ratio from Cloern et al. (1995) (lower panel) to observations at TENATSO from: POS 332 cruise (red circle), POS 348 (red triangle), POS 320/1 (green circle), MERIAN 2008 (green triangle), Meteor 68/3 (blue circle), MSM 08/2 (green square). The gray area shows the variability of modelled Chl.

et al., 2004). On the other hand, diazotrophs have higher $\mathrm{Fe}$ requirement and might also influence $\mathrm{Fe}$ availability significantly.

\subsection{Aggregation and particle distribution and fluxes}

Aggregation rates have an influence on the vertical distribution of organic and inorganic particles, and by that also on the removal of dissolved iron from the water column, yet there exists very little information on their values. We therefore conducted a series of sensitivity experiments (Table 3) varying all four different aggregation rates in our model setup in parallel.

The aggregation rates strongly influence the distribution of lithogenic material over the three model size classes, especially at depth. This becomes evident from the distribution of lithogenic material over all three particle size classes at $1000 \mathrm{~m}$ depth (last three columns in Table 3): while in runs $\mathrm{A} 0$ and $\mathrm{A} 1$, all lithogenic material remains in the smallest size class, in runs A2, A3 and A4, virtually all lithogenic material is found within the larger aggregates. Neither of the two extremes is compatible with the sediment trap size distributions by Ratmeyer et al. (1999), who found that the average size of lithogenic material-bearing particles varies between 12 and $19 \mu \mathrm{m}$. At their sediment trap location, somewhat south of the Cape Verde islands, the lithogenic flux at $1000 \mathrm{~m}$ depth in the size range from 6 to $11 \mu \mathrm{m}$ varies between 5 and $70 \mathrm{mg} \mathrm{m}^{-2} \mathrm{~d}^{-1}$, and between 3 and $30 \mathrm{mg} \mathrm{m}^{-2} \mathrm{~d}^{-1}$ in the size range from 20 to $63 \mu \mathrm{m}$. The only model run that is qualitatively compatible to this flux size distribution is model run $\mathrm{R}$, in which the lithogenic flux in the smaller two size classes together varies between 5 and $10 \mathrm{mg} \mathrm{m}^{-2} \mathrm{~d}^{-1}$, and in the larger size class between 8 and $52 \mathrm{mg} \mathrm{m}^{-2} \mathrm{~d}^{-1}$. Without sediment flux directly from the TENATSO site we are not able to infer whether the somewhat larger fraction of the flux carried by large particles in model run R, compared to Ratmeyer et al. (1999), points to a slight overestimate of aggregation or is simply an effect of local conditions.

The time-averaged vertical flux of lithogenic material must be independent of depth due to conservation of mass. As the flux is dominated by the sinking flux, a shift from smaller, slowly sinking particles to larger, faster particles, is accompanied by a decrease in the total concentration of suspended lithogenic material (Fig. 5a): with low or no aggregation (runs A0 and A1), the vertical profile is almost constant, the small decrease with depth being caused by diffusive fluxes in addition to sinking. With the aggregation rate from Ruiz et al. (2002) we obtain a continuous decrease of the concentration with depth to about $14 \%$ of the surface values, caused by a slow shift to a larger average particle size. With higher aggregation rates (A2, A3, A4), the profile becomes constant below a certain depth, indicating that all material has been transferred to the largest particle class. In runs A3 and $\mathrm{A} 4$, even the surface concentration of lithogenic material decreases, although the smallest particles still dominate the concentration.

The third column of Table 3 also shows that the choice of the aggregation rate has a comparatively small influence on the sinking flux of organic material both directly under the mixed layer and at $1000 \mathrm{~m}$ depth. Fluxes at $1000 \mathrm{~m}$ depth are between $18 \%$ and $20 \%$ of the flux in $100 \mathrm{~m}$ depth. From the empirical depth dependency by Martin et al. (1987) we would have expected a ratio between the fluxes at 1000 and $100 \mathrm{~m}$ of about $15 \%$. Absolute values of the fluxes are also somewhat higher than measured values in sediment traps from the region, the best agreement being shown by model run $\mathrm{R}$ with $15.1 \mathrm{mg} \mathrm{C} \mathrm{m}^{-2} \mathrm{day}^{-1}$. Organic carbon flux at a mooring to the south of Cape Verde is between 2.0 and $12.7 \mathrm{mg} \mathrm{C} \mathrm{m}^{-2}$ day $^{-1}$ (Fischer and Wefer, 2000), for the Northwest African upwelling it varies between 3.5 and $9.3 \mathrm{mg} \mathrm{C} \mathrm{m}^{-2}$ day $^{-1}$ (Lutz et al., 2002) and for the mesotrophic site of the EUMELI program it is about $10 \mathrm{mg} \mathrm{C} \mathrm{m}^{-2}$ day $^{-1}$ (Bory et al., 2001).

Based on these results we conclude that an aggregation rate that corresponds to the data-based estimate by Ruiz et al. (2002) is best compatible with the available sediment trap information from regional sediment traps. We acknowledge, however, that, given the available data, we are probably not 

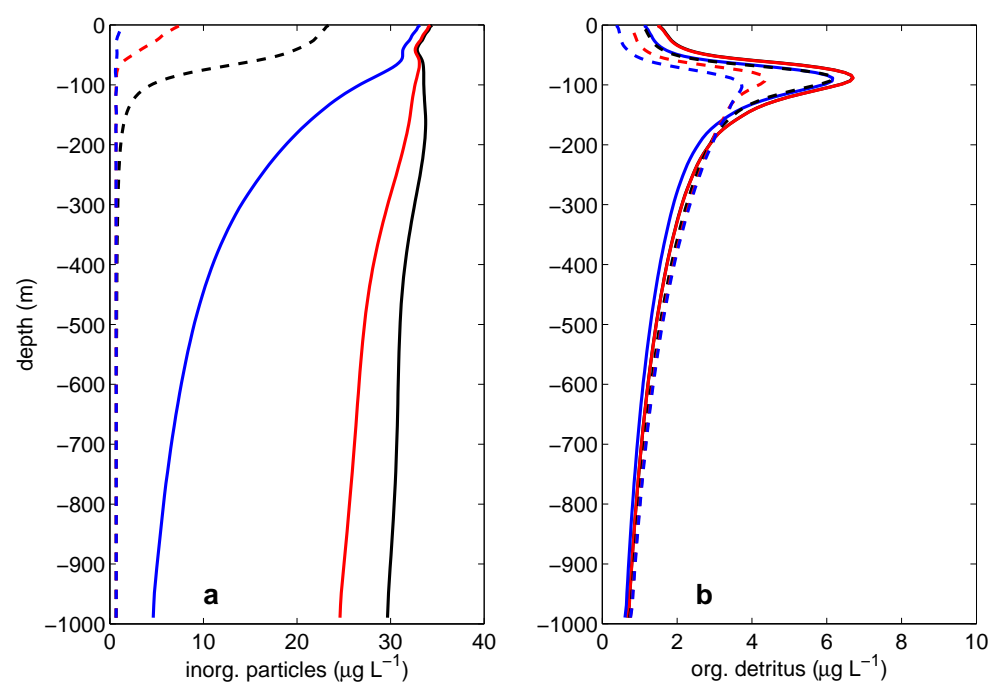

Fig. 5. Vertical distribution of modelled inorganic (left) and organic (right) particles of the sensitivity model runs with respect to aggregation rates, $\mu \mathrm{g} \mathrm{L}^{-1}$. The aggregations rates and the numbers of the runs are shown in Table 3. Solid black line: A0, solid red line: A1, solid blue line: R, dashed black line: A2, dashed red line: A3 and dashed blue line: A4.

able to constrain the aggregation rate more than by about an order of magnitude from our sensitivity analysis.

In model run $\mathrm{R}$, the ratio between organic and inorganic matter at the surface varies between 0.5 and 6.5 , with a mean of 2.5, much lower than the average of 45 from the openocean measurements of Emery and Honjo (1979). This indicates that, although open ocean, TENATSO is still in a highdust deposition region. Near the surface, however, the detritus fraction of biogenic matter is, however, much smaller than the total biogenic matter. If one focuses on sinking material alone the removal of dissolved $\mathrm{Fe}$ by adsorption onto sinking particles is dominated by lithogenic particles (Fig. 5). Deeper in the water column, the ratio of organic:inorganic fraction in aggregates is shifted towards lower values with depth due to remineralisation. In small aggregates, the organic fraction falls below a few percent at about $400 \mathrm{~m}$ depth, at which limit the aggregates might become unstable (Passow, 2004). In large aggregates, this limit is not reached within the upper $1000 \mathrm{~m}$.

The percentage of small particles in the organic fraction of aggregates within the mixed layer varies between $50 \%$ and $90 \%$ annually and remains almost uninfluenced by the aggregation rate for the runs A0, A1, R, A2; only at aggregation rates that are larger by a factor of hundred or more than the value in R (runs A3 and A4), aggregation begins to deplete small aggregates within the mixed layer. This points to a strong role of zooplankton excretion rather than aggregation for the genesis of the larger organic particles in our model.

There are certainly a number of shortcomings in our parameterisation of vertical sinking: minerals add density to aggregates (Armstrong et al., 2002; Francois et al., 2002; Klaas and Archer, 2002) but also decrease their size and fragment them into smaller particles if reaching a certain concen- tration (Hamm, 2002; Passow and De la Rocha, 2006). The model resolves only three particle size classes, and does not take into account disaggregation of particles and the variation of sinking speed with the mineral load. As sediment trap data directly from the TENATSO site becomes available a validation of this aspect of the model and a better judgment of model deficiencies will become possible.

\subsection{Results from the chemical model}

\subsubsection{Organic complexation}

Weak ligands are typically more abundant than strong ligands and predominate deeper in the water column (Rue and Bruland, 1995, 1997). They are therefore important in controlling the structure of $\mathrm{Fe}$ profile below annual mixed layer. In our model, the abundance of weak ligands in deeper waters is mainly determined by release during remineralisation of organic matter and by the rate of microbial degradation, while their photoreactivity and uptake by phytoplankton are also significant loss processes in surface waters.

In a sensitivity study with respect to the decay rate of weak ligands, we ran the model assuming four different degradation rates for weak ligands, $\gamma_{l w}$. In the first study, we used a typical degradation rate for marine DOM of $1 /(26$ days $)$ (Amon and Benner, 1994), the same as for strong ligands, while in the other three, we used one tenth and one hundredth of that value, and completely excluded $\mathrm{L}_{\mathrm{we}}$ degradation. In an additional run, we changed the temperature dependency of all remineralisation rates, including that of sinking organic particles. 
In the first sensitivity run, the concentration of total ligands ranges from 0.1 to $1 \mathrm{nmol} \mathrm{L}^{-1}$ with a subsurface maximum at $100 \mathrm{~m}$ (data not shown). Below this maximum, ligand concentration decreases dramatically with depth. This could be an indication of a too high degradation rate or a too low temperature dependence of microbial activities. This was tested in the remaining sensitivity studies.

In the run with $\gamma_{l w}$ set to $1 /(260$ days $)$, ligand concentration still decreases strongly with depth below its subsurface maximum (Fig. 6). At the end of the 30-year integration, the deep concentration falls to $0.1 \mathrm{nmol} \mathrm{L}^{-1}$ and approaches a steady state. The ligand concentration of the run with $\gamma_{l w}$ set to $1 /(2600$ days $)$ is higher and closer to the observations, showing a subsurface maximum at $80 \mathrm{~m}$ due to the production of strong ligands and a maximum of $2 \mathrm{nmol} \mathrm{L}^{-1}$ between 150 and $200 \mathrm{~m}$ due to remineralisation. However, it still decreases with depth and the values at $1000 \mathrm{~m}$ depth are $60 \%$ lower than the maximum. Depth-integrated concentration decreases with time. Although the decrease slows down with time, a steady state is not yet obtained at the end of the 30-year integration. Without degradation, finally, ligand concentrations are unrealistically high with a maximum of $190 \mathrm{nmol} \mathrm{L}^{-1}$ between 300 and $400 \mathrm{~m}$ at the end of the 30year integration, indicating that microbial degradation can not be neglected for simulating a reasonable concentration of weak ligands.

To test the effect of temperature dependence, we changed the factor by which remineralisation decreases with a 10 degree temperature decrease (Q10) from 2 to 3 in a further run with a degradation rate $\gamma_{l w}$ of $1 /(2600$ days $)$, keeping the remineralisation rate at $20^{\circ} \mathrm{C}$ constant (Eq. A8). Above the isothermal curve of $20^{\circ} \mathrm{C}$ between 75 and $85 \mathrm{~m}$, the stronger remineralisation leads to a lower ligand concentration (Fig. 6). From its subsurface maximum at $100 \mathrm{~m}$ to $1000 \mathrm{~m}$ depth, ligand concentrations become nearly constant with depth, which is comparable to the profile from Boye et al. (2006). However, another effect of the stronger temperature dependence is the increase of POC export at depth because of the slower remineralisation of detritus. The export at $1000 \mathrm{~m}$ rises from 15 to $38 \mathrm{mgC} \mathrm{m}^{-2} \mathrm{~d}^{-1}$, exceeding observations (see Sect.3.3 Aggregation and particle distribution and fluxes). We therefore reject this model setup as a plausible hypothesis.

In summary, the model sensitivity runs show that weak ligands probably contain a fraction of more refractory material with decay times longer than 2600 days (approximately 7 years). This is consistent with hypotheses from other researchers (Hunter and Boyd, 2007; Kondo et al., 2008). In consequence, the model would have to be run for a longer integration period than 30 years for the concentration of weak ligands to reach a steady state. Over such long timeperiods, however, lateral advection becomes non-negligible and could also affect the the local concentration of weak ligands (Kondo et al., 2008). These processes can not be represented within our one-dimensional model and we thus re-

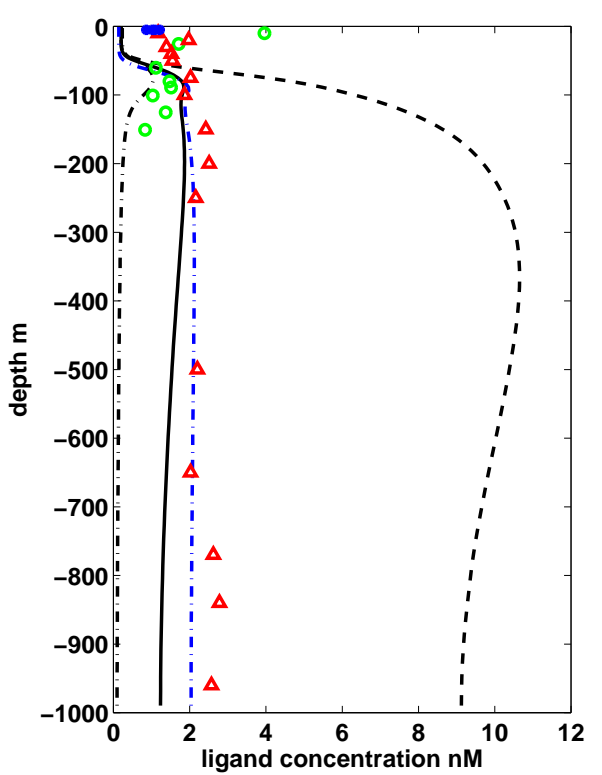

Fig. 6. Annual mean profiles of total ligands in the sensitivity study with different remineralisation rates for weak ligands and Q10, nmol L ${ }^{-1}$. Black dash-dot line: Q10=2, $\gamma_{l w}=1 /(260$ days $)$; black solid line: Q10 $=2, \gamma_{l w}=1 /(2600$ days $)$; black dashed line: Q10=2, $\gamma_{l w}=0$; blue dash-dot line: $\mathrm{Q} 10=3, \gamma_{l w}=1 /(2600$ days $)$. Colour symbols show the observations from: Boye et al. (2006) (red triangle), Gerringa et al. (2006) (green circle) and Rijkenberg et al. (2008) (blue dot, only surface data).

frained from extending our model integration period for even longer. This clearly is a question that can only be modelled successfully in three dimensions.

However, a realistic profile of ligands, especially in the deep ocean, is a prerequisite for further modelling iron speciation at depth and its influence on the removal of dissolved iron through particles. As we are not able to obtain a weak ligand profile that is both realistic and stable within the integration time of our model, we introduced a restoring of the concentration of total weak ligands towards a constant value for all further model runs, so that iron speciation and losses will not be affected by too little complexation. Weak ligands are restored throughout the water column with a rate of $0.1 \mathrm{~d}^{-1}$ towards $2.5 \mathrm{nmol} \mathrm{L}^{-1}$, a typical ligand concentration in the deep Atlantic Ocean (Boye et al., 2006; Gledhill and van den Berg, 1994; Witter and Luther III, 1998). This restoring is weak enough so that loss processes near the surface (biological uptake and photochemical decay) still lead to the observed vertical gradient of total weak ligand concentration there.

Our modelled total strong ligands (Fig. 7) have a high abundance from 40 to $100 \mathrm{~m}$ and decline rapidly with depth below the subsurface maximum, which is consistent with their production by phytoplankton and degradation by microbes. Some observations show a qualitatively similar vertical distribution of strong ligands (Rue and Bruland, 1995, 
1997; Gerringa et al., 2006), although in other oceanic regions. The subsurface maximum is at and a little below the depth of the chlorophyll maximum in the model which is also observed by Gerringa et al. (2006).

Modelled concentrations of total ligands increase with depth in surface waters and reach their maximum around $3 \mathrm{nmol} \mathrm{L}^{-1}$ at $80 \mathrm{~m}$. They range in the same magnitude as the observations (Fig. 7). However, some observed high values can not be included in the range of modelled variability which might be caused by an overestimation of photolysis of organic complexes. Below the maximum, the modelled mean concentration decreases to $2.5 \mathrm{nmol} \mathrm{L}^{-1}$ at $150 \mathrm{~m}$ and keeps constant from there to $1000 \mathrm{~m}$ depth due to the restoring of weak ligands. This profile reproduces the measured profile by Boye et al. (2006) quite well.

In summary, our model results agree with the qualitative picture put forward by Hunter and Boyd (2007) that the low vertical gradients of ligand concentrations within the deep ocean indicate that the ligand pool contains a fraction that is not decomposed very quickly by bacteria (our model results indicate a degradation time-scale of longer than a decade, from the value of $\gamma_{l w}$ in the most realistic model run and a temperature dependency with $\mathrm{Q} 10=2$ ), and that is produced from the remineralisation of sinking particles. Strong ligands on the other hand, which are probably directly produced by procaryotes in response to iron deficiency, could well be degraded like most non-refractory dissolved organic matter (Amon and Benner, 1994).

\subsubsection{Modelled DFe concentration}

Measured profiles of dissolved iron (DFe) often show a nutrient-like distribution: the minimal concentration is in surface waters and averages globally $0.07 \mathrm{nmol} \mathrm{L}^{-1}$; like for other remineralised nutrients (Broecker and Peng, 1982), DFe concentrations increase with depth. However, unlike other nutrients, deep-water DFe show no obvious inter-ocean fractionation (Johnson et al., 1997). Concentrations in the deep ocean are rather constant near $0.6 \mathrm{nmol} \mathrm{L}^{-1}$ away from the influence of continental shelves, with lower values in the Southern Ocean and higher values in the tropical Atlantic (Johnson et al., 1997; Wu and Boyle, 2002; Boye et al., 2006; Sarthou et al., 2007). This has been ascribed to removal of DFe through particles.

Deeper in the water column, DFe concentration in our model is mainly determined by iron release by detritus remineralisation and removal by sinking particles, whereas in surface waters, other processes like dust input, photochemical reactions and biological uptake play a more important role. Iron release from remineralisation of organic matter decreases with depth due to its dependence on detritus abundance and temperature. We would therefore expect a continuous decrease of DFe in deeper waters, if there was no redissolution of iron from its particle-adsorbed forms. The removal of DFe at depth is dominated by the formation and

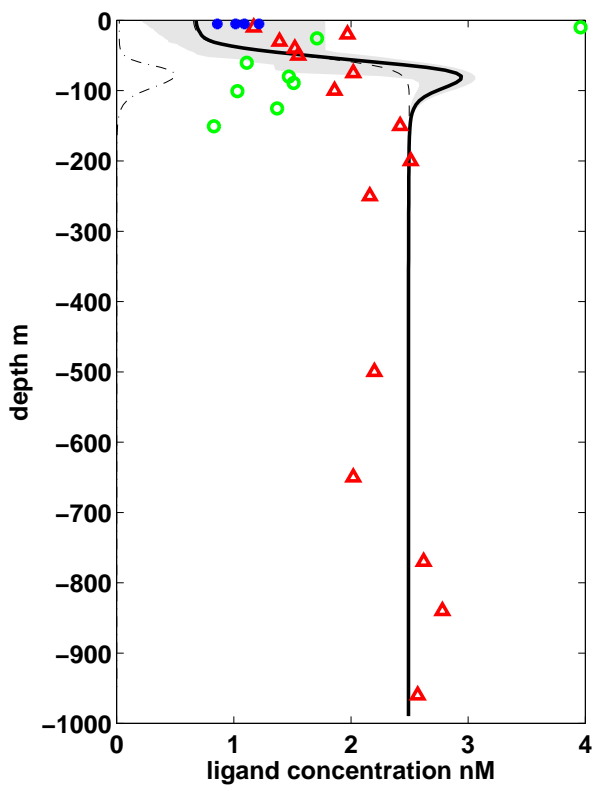

Fig. 7. Modelled annual mean profile of total ligands (solid), strong (dash-dot) and weak ligands (dashed), $\mathrm{nmol} \mathrm{L}^{-1}$. The gray area shows the variability of modelled total ligand. Colour symbols show the observations from: Boye et al. (2006) (red triangle), Gerringa et al. (2006) (green circle) and Rijkenberg et al. (2008) (blue dot, only surface data).

adsorption of colloids to sinking particles. Fluxes of these processes are 2 orders of magnitude larger than the fluxes due to direct scavenging of $\mathrm{Fe}(\mathrm{III})$ '.

We conducted a sensitivity study with respect to the rate of redissolution or desorption of particulate iron $\left(k_{p d}\right)$. In the sensitivity model runs, the redissolution rate of particulate iron is set to be $0,0.015$ and $0.15 \mathrm{~d}^{-1}$. Without redissolution, $\mathrm{DFe}$ is in steady state after 20 modelling years. DFe concentration decreases continuously with depth as expected and reaches a value of $0.07 \mathrm{nmol} \mathrm{L}^{-1}$ at $1000 \mathrm{~m}$ (Fig. 8, left), in contrast to observations. In the other two runs, increasing $k_{p d}$ leads to an increase of DFe concentration below ca. $80 \mathrm{~m}$, the depth of the subsurface chlorophyll maximum and the highest particle concentration (see Sect. 3.3 Aggregation and particle distribution and fluxes). With $k_{p d}=0.015 \mathrm{~d}^{-1}$, modelled DFe shows a nearly constant concentration in deeper waters which is very close to the so far only DFe profile measured at TENATSO site (Fig. 8 left, deep DFe profile data courtesy of Micha Rijkenberg, unpublished data). We also compared model results to the deep DFe concentrations by Boye et al. (2006) from a more northerly region near the Canary Islands (Fig. 8). With $k_{p d}=0.15 \mathrm{~d}^{-1}$, the vertical DFe profile increases more strongly with depth, exceeding the values by Rijkenberg, and coming closer to the profile by Boye et al. (2006). It has to be noted, though, that in both cases with $k_{p d}>0$ the DFe profiles are not completely stable at the end of the 30-year integration period, with deep 

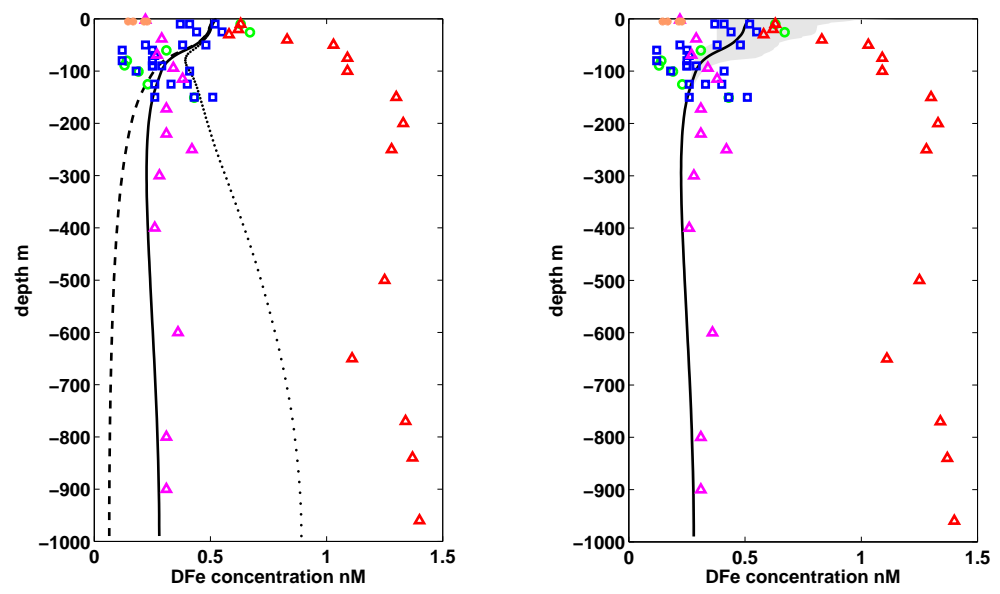

Fig. 8. Modelled annual mean profiles of DFe concentration in the sensitivity study with different redissolution rates $\left(k_{p d}\right)$ of $\mathrm{Fe}_{p}(\mathrm{left})$ and compared to measured profiles (right), $\mathrm{nmolL} \mathrm{L}^{-1}$. Dashed line: $k_{p d}=0$; solid line: $k_{p d}=0.015$, dotted line: $k_{p d}=0.15$. Modelled DFe variability is shown with gray area. Colour symbols show the observations from: Rijkenberg et al. (2008) (orange dot) and Rijkenberg (unpublished data from the POS 332 cruise, magenta triangle), Sarthou et al. (2007) (blue square), Gerringa et al. (2006) (green circle), and Boye et al. (2006) (red triangle).

concentrations still slightly increasing with time. In the case with $k_{p d}=0.015 \mathrm{~d}^{-1}$ this increase is about $5 \%$ over the last 5 model years. Without more observations, it is impossible to estimate the value of $k_{p d}$ more exactly, but we would argue from the comparison to the data by Rijkenberg that $k_{p d}=0.015 \mathrm{~d}^{-1}$ is not a bad choice. We introduced the redissolution of $\mathrm{Fe}_{\mathrm{p}}$ with $0.015 \mathrm{~d}^{-1}$ for further analysis of $\mathrm{Fe}$ speciation in the model.

Modelled DFe profile (Fig. 8 right) shows high concentration in surface waters which decreases rapidly between 50 and $80 \mathrm{~m}$, caused by high biological uptake. Below the deep chlorophyll maximum at $80 \mathrm{~m}$, DFe decreases moderately till $200 \mathrm{~m}$ and reaches a minimum of $0.25 \mathrm{nmol} \mathrm{L}^{-1}$. Below that, the concentration increases slightly with depth and varies around $0.3 \mathrm{nmol} \mathrm{L}^{-1}$ at $1000 \mathrm{~m}$ depth.

The modelled DFe surface concentration shows a clear seasonal pattern with higher concentration in winter (from December to March) and in late summer and autumn (from August to September). The high concentration in winter is mainly caused by high dust deposition and in summer additionally by the shallower mixed layer depth. The surface concentration varies from 0.4 to $0.9 \mathrm{nmol} \mathrm{L}^{-1}$ and its annual average is ca. $0.5 \mathrm{nmol} \mathrm{L}^{-1}$. Overlaid on this seasonal variability there is considerable interannual and also shortterm variability due to the episodic nature of dust deposition. There are a few measurements of surface DFe near TENATSO: Sarthou et al. (2003): $0.28 \mathrm{nmol} \mathrm{L}^{-1}$, Sarthou et al. (2007): $0.37-0.52 \mathrm{nmol} \mathrm{L}^{-1}$ and Rijkenberg et al. (2008): $0.1-0.4 \mathrm{nmol} \mathrm{L}^{-1}$ ). The modelled variability covers most observations except for the low concentrations from Rijkenberg et al. (2008). The interannual variability of dust deposition might play a role, since the surface flux in our model is based on the data for 1990-1995. The fixed solubil- ity and Fe content in the model also might impact the variability of DFe concentration. Another reason could be the simplification of the ecosystem model which only considers one average phytoplankton with the average Fe requirement. It is known that diazotrophs have higher Fe requirement and occur in high abundance in tropical North Atlantic (Tyrrell et al., 2003; Carpenter et al., 2004). This might lead to an underestimation of biological iron uptake in our model.

$\mathrm{Fe}_{\mathrm{col}}$ in the model represents the inorganic colloidal iron which is formed by $\mathrm{Fe}(\mathrm{III})^{\prime}$ and removed from the dissolved pool by colloidal aggregation. The modelled $\mathrm{Fe}_{\mathrm{col}}: \mathrm{Fe}_{\mathrm{sol}}$ ratio is nearly constant below $150 \mathrm{~m}$ and reaches $1: 40$ at $1000 \mathrm{~m}$. Some recent studies found that about half of DFe in the deep ocean is colloidal (Wu et al., 2001; Cullen et al., 2006; Bergquist et al., 2007). This indicates that a fraction of colloidal iron must be prevented from removing processes ( $\mathrm{Wu}$ et al., 2001; Cullen et al., 2006; Bergquist et al., 2007). One possible explanation of the discrepancy between our model and the observations could be the co-existence of organic colloids. Organic complexes of iron are found in both soluble and colloidal form (Wu et al., 2001; Cullen et al., 2006). It is reported that remineralisation releases $\mathrm{Fe}_{\text {lig }}$ preferentially in colloidal form (Bergquist et al., 2007). We suggest that organic colloids could be kept longer in the dissolved pool and be more biologically available than the inorganic colloids by transformation into soluble organic complexes via ligand exchange reactions. Hence, introducing organic colloidal iron in further modelling works may be helpful for understanding the observed $\mathrm{Fe}_{\text {col }}: \mathrm{Fe}_{\text {sol }}$ ratio in deep waters, which of course must be supported by more studies on the colloidal nature of iron and Fe-binding ligands (Hunter and Boyd, 2007). 

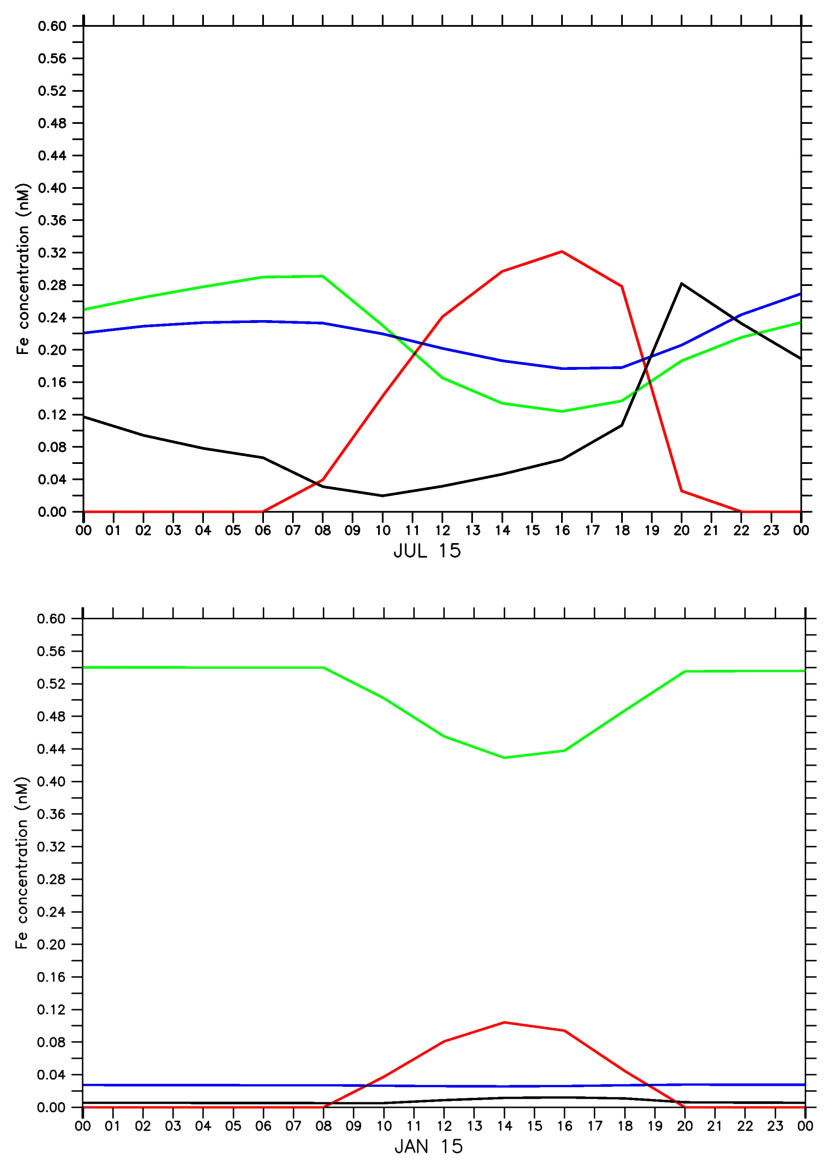

Fig. 9. Modelled diurnal variability of Fe species in summer (upper panel) and winter (lower panel). Fe(III)': black, Fe(II)': red, $\mathrm{Fe}_{\mathrm{col}}$ : blue, $\mathrm{Fe}_{\text {lig }}$ : green.

\subsubsection{Diurnal variation of Fe speciation}

Because of the influence of $\mathrm{O}_{2}^{-}$and $\mathrm{H}_{2} \mathrm{O}_{2}$ on the redox state of $\mathrm{Fe}$, the modelled $\mathrm{Fe}$ speciation near the surface shows a strong diurnal variability. $\mathrm{O}_{2}^{-}$is mainly produced by the photo-oxidation of coloured dissolved organic matter (CDOM). We assumed a production rate in the range of the rates estimated for open ocean by Micinski et al. (1993) and made it proportional to light intensity in our model. Thus the concentration of $\mathrm{O}_{2}^{-}$increases after sunrise, reaches its maximum at noon and then falls to zero after sunset. $\mathrm{H}_{2} \mathrm{O}_{2}$ has a longer lifetime than $\mathrm{O}_{2}^{-}$, especially in the absence of $\mathrm{Fe}(\mathrm{II})$ ', and does not vanish during the night. Its rate of production which is proportional to $\left[\mathrm{Fe}(\mathrm{II})^{\prime}\right]\left[\mathrm{O}_{2}^{-}\right]$has a strong maximum at noon and rapidly decreases afterwards. Its rate of consumption, which is proportional to [ $\left.\mathrm{Fe}(\mathrm{II})^{\prime}\right]\left[\mathrm{H}_{2} \mathrm{O}_{2}\right]$ has a lower but broader maximum. In consequence, the concentration of $\mathrm{H}_{2} \mathrm{O}_{2}$ reaches its maximum 3-4 h after noon, when the loss becomes larger than the production.

Reduction of $\mathrm{Fe}(\mathrm{III})$ ' mediated by $\mathrm{O}_{2}^{-}$is the most important source of $\mathrm{Fe}(\mathrm{II})^{\prime}$ in the model and its rate is more than 100 times the rate of all the direct photo-reductions together. The concentration of $\mathrm{Fe}$ (II)' is mainly controlled by photo-reduction mediated by $\mathrm{O}_{2}^{-}$and oxidation by $\mathrm{H}_{2} \mathrm{O}_{2}$ and $\mathrm{O}_{2}^{-}$. With the sunrise, $\mathrm{Fe}(\mathrm{II})^{\prime}$ increases quickly with increasing light intensity and $\mathrm{O}_{2}^{-}$concentration (Fig. 9). Photoreduction of ferric iron outweighs the oxidation till shortly after noon. In the afternoon, $\mathrm{H}_{2} \mathrm{O}_{2}$ reaches its maximum and light intensity becomes lower. The balance between photoreduction and oxidation is shifted, leading to a rapid decrease of Fe(II)'. During the night, the concentration of Fe(II)' is close to 0 because of its extremely short lifetime.

Concentration of $\mathrm{Fe}(\mathrm{III})$ ' is mainly controlled by $\mathrm{Fe}(\mathrm{II})$ ' oxidation and organic complexation. During the day in summer, Fe(III)' has a low concentration and shows a rapid increase after sunset. However, organic complexation leads to a decrease of $\mathrm{Fe}$ (III)' after 08:00 p.m. again, such that $\mathrm{Fe}_{\text {lig }}$ (both $\mathrm{FeL}_{\mathrm{str}}$ and $\mathrm{FeL}_{\mathrm{we}}$ ) are the dominant forms during the night in summer and throughout the daily cycle in winter.

$\mathrm{Fe}_{\mathrm{col}}$ shows a lower sensibility to changes in light than $\mathrm{Fe}_{\text {lig }}$, since colloid formation is a much slower process than oxidation and organic complexation (Rose and Waite, 2003a).

The pattern of the daily cycle in winter (Fig. 9) is similar to that in summer, but shows a smaller amplitude caused by the weaker irradiance and deeper mixed layers in winter. $\mathrm{Fe}_{\text {lig }}$ has a much higher concentration than in summer. Besides the decrease of photoredox reaction rate, higher biological uptake in summer also plays a role.

Copper redox reactions compete for superoxide with iron (Voelker and Sedlak, 1995) and thus influence the amplitude of the daily cycle of superoxide concentration and Fe speciation. We estimated total copper concentration from the measurements of van der Loeff et al. (1997) and assumed that $\mathrm{Cu}(\mathrm{II})$ is strongly complexed (Moffett, 1995). Redox reactions of copper are considered in our model in the same way as Weber et al. (2005). Increasing $\mathrm{Cu}$ concentration from $1 \mathrm{nmol} \mathrm{L}^{-1}$ to $5 \mathrm{nmol} \mathrm{L}^{-1}$ in our model reduces the daily amplitude of $\mathrm{Fe}(\mathrm{II})^{\prime}$ to a third of its value.

Because Fe redox speciation has not yet been measured at the TENATSO site, we compared the modelled $\mathrm{H}_{2} \mathrm{O}_{2}$ with observations which is a measure for photochemical reactions of iron. The modelled $\mathrm{H}_{2} \mathrm{O}_{2}$ integrated for $0-200 \mathrm{~m}$ ranges from 3 to $7 \mathrm{mmol} \mathrm{m}^{-2}$ and is comparable with a $\mathrm{H}_{2} \mathrm{O}_{2}$ inventory of about $3.7 \mathrm{mmol} \mathrm{m}^{-2}$ for the same depth interval measured in the vicinity (Steigenberger and Croot, 2008).

\section{Summary and conclusions}

A one-dimensional model of iron biogeochemistry developed for the BATS site (Weber et al., 2007) has been extended for the TENATSO site with a more complex description of particle aggregation and sinking and origin and fate of organic Fe-binding ligands. 
Despite the simplicity of the NPZD-type ecosystem model, simulated chlorophyll a concentration and seasonality of primary production at the TENATSO site are in agreement with observations. Time-averaged primary production ranges between the observations at the oligotrophic and mesotrophic stations in the tropical Eastern North Atlantic. Export production varies seasonally between 6 and $20 \%$ which is consistent with published values. These provide good boundary conditions for modelling Fe uptake and release as well as the biological origin and decay of organic ligands.

Modelled particles are classified due to size and composition. Particle aggregation and sinking are described based on the calculation of coagulation kernels and data-based estimation of aggregation rates. Modelled fluxes of inorganic particles and their size distribution at $1000 \mathrm{~m}$ are qualitatively compatible with the measurements from Ratmeyer et al. (1999), whereas the POC export is somewhat higher than measured values from regional sediment traps, which might be caused by the simplified classification and constant sinking rates of particles.

Sources and decay of organic ligands are connected to biological activities. The profile of dissolved iron is strongly influenced by the abundance of organic ligands. Modelled strong ligands have a high abundance near the surface and decline rapidly below the deep chlorophyll maximum, in qualitative agreement with observations. However, a restoring of total weak ligands towards a constant value is required for reproducing the observed nutrient-like profile of weak ligands. This possibly indicates that weak ligands contain a fraction of more refractory material whose decay time is longer than the assumed 7 years in the model, and that the dynamics of this refractory material cannot be described well with a onedimensional model which takes only local processes into account.

We investigated a number of hypotheses on processes affecting Fe speciation with sensitivity studies. Our best model runs come close to observed DFe concentrations at the surface and at depth near the TENATSO station. The reproduction of the DFe profile by Rijkenberg requires a redissolution of DFe from particle-adsorbed iron with a timescale around 60 days. The low $\mathrm{Fe}_{\mathrm{col}}$ : $\mathrm{Fe}_{\text {lig }}$ ratio in the model suggests introducing organic colloids into the model in future work.

The model extension on particle dynamics and ligand source and fate provide a better understanding of Fe speciation and biogeochemical cycle. This process-based understanding can be applied for explaining and reproducing the reality, when more observations on particle and ligand distribution as well as Fe speciation directly at TENATSO site become available.

\section{Appendix A}

\section{Model equations}

The rate of change of biogeochemical variables can be separated into a biogeochemical and a physical part:

$\frac{\partial}{\partial t} X=\mathrm{BIO}+M(X, z)$

where advection and mixing are taken into account in the physical part $M(X, z)$. Here $M$ stands for the advection and mixing operator and $X$ is the mixed compound. The biogeochemical rate of change is described by corresponding sources minus sinks.

The change of the biological variables $N, P, Z$ and $D$ (in $\mu \mathrm{mol} \mathrm{L}-1)$ is described by:

$$
\begin{gathered}
\frac{\partial}{\partial t} N=\gamma_{d} f_{T}\left(D+A_{\text {or }}\right)+\gamma_{z b} f_{T} Z+\gamma_{p} f_{T} P+\gamma_{l} f_{T} \\
\left(\mathrm{~L}_{\mathrm{str}}+\mathrm{L}_{\mathrm{we}}\right)-\mu P+M(N, z)
\end{gathered}
$$

$$
\begin{aligned}
\frac{\partial}{\partial t} P & =\left(\mu-\gamma_{p} f_{T}\right) P-f_{G} Z \\
& -\gamma_{p^{2}} P^{2}-r_{L} \gamma_{l p} f_{Q} P+M(P, z)
\end{aligned}
$$

$\frac{\partial}{\partial t} Z=\gamma_{z a} f_{G} Z-\gamma_{z b} f_{T} Z-\gamma_{z^{2}} Z^{2}+M(Z, z)$

Detritus is subdivided into two size classes: $D_{s}$ for small and $D_{l}$ for large detritus. We use the same symbols for organic part of small aggregates and large aggregates, respectively, because we treat them same as the detritus in particle aggregation, sinking and remineralisation.

$$
\begin{gathered}
\frac{\partial}{\partial t} D_{S}=\gamma_{p^{2}} P^{2}+\left(1-\gamma_{z a}\right) f_{G} Z-\left(\gamma_{d}+r_{L} \gamma_{l d}\right) \\
f_{T} D_{S}-k_{\mathrm{coag} 2} D_{S}\left(D_{S} r_{\mathrm{m}: \mathrm{N}}+A_{S}\right)-k_{\mathrm{coag} 3} D_{S} \\
\left(D_{L} r_{\mathrm{m}: \mathrm{N}}+A_{L}\right)-w_{S} \frac{\partial D_{S}}{\partial z}+M\left(D_{S}, z\right)
\end{gathered}
$$

$$
\begin{gathered}
\frac{\partial}{\partial t} D_{L}=\gamma_{z^{2}} Z^{2}-\left(\gamma_{d}+r_{L} \gamma_{l d}\right) f_{T} D_{L}+k_{\mathrm{coag} 2} D_{S} \\
\left(D_{S} r_{\mathrm{m}: \mathrm{N}}+A_{S}\right)+k_{\mathrm{coag} 3} D_{S}\left(D_{L} r_{\mathrm{m}: \mathrm{N}}+A_{L}\right) \\
-w_{l} \frac{\partial D_{L}}{\partial z}+M\left(D_{L}, z\right)
\end{gathered}
$$

where $\mu$ is the growth rate of phytoplankton regarding light, temperature and nutrient limitation. $\gamma_{l p} f_{Q} P$ describes the loss of nitrogen due to the excretion of Fe-binding ligands and $r_{L}$ is a factor converting ligand nitrogen $\left(\mathrm{nmol} \mathrm{L}^{-1}\right)$ into phytoplankton and detritus nitrogen $\left(\mu \mathrm{mol} \mathrm{L}^{-1}\right)$. The loss of zooplankton by its mortality $\gamma_{z^{2}} Z^{2}$ is considered as a source of organic aggregates. The grazing function $f_{G}$ depends on 
the maximal grazing rate $g$, the prey capture rate $\epsilon$ and phytoplankton concentration:

$f_{G}=\frac{g \epsilon P^{2}}{g+\epsilon P^{2}}$

The growth and remineralisation rate are related to temperature by:

$f_{T}=0.9 C_{2}^{T(z)}$

which represents a temperature dependence for $\mathrm{Q} 10=2$.

Further sinking particles are dust particles $B$, the inorganic fraction of small aggregates $A_{S}$ and of large aggregates $A_{L}$ (all in $\mathrm{kg} \mathrm{L}^{-1}$ ). Coagulation is described by a coagulation constant $k_{\text {coag }}$ times the product of concentration of the two particle classes participating in the coagulation.

$$
\begin{aligned}
\frac{\partial}{\partial t} B & =F_{\mathrm{dust}}-k_{\text {coag } 1} B\left(D_{S} r_{\mathrm{m}: \mathrm{N}}+A_{S}\right) \\
& -k_{\mathrm{coag} 4} B\left(D_{L} r_{\mathrm{m}: \mathrm{N}}+A_{L}\right)-w_{d} \frac{\partial B}{\partial z}+M(B, z)
\end{aligned}
$$

$$
\begin{gathered}
\frac{\partial}{\partial t} A_{S}=k_{\mathrm{coag} 1} B\left(D_{S} r_{\mathrm{m}: \mathrm{N}}+A_{S}\right)-k_{\mathrm{coag} 3} A_{S}\left(D_{L} r_{\mathrm{m}: \mathrm{N}}+A_{L}\right) \\
-k_{\mathrm{coag} 2} A_{S}\left(D_{S} r_{\mathrm{m}: \mathrm{N}}+A_{S}\right)-w_{S} \frac{\partial A_{S}}{\partial z}+M\left(A_{S}, z\right) \quad(\mathrm{A} 10)
\end{gathered}
$$

$$
\begin{gathered}
\frac{\partial}{\partial t} A_{L}=k_{\mathrm{coag} 4} B\left(D_{L} r_{\mathrm{m}: \mathrm{N}}+A_{L}\right)+k_{\mathrm{coag} 3} A_{S}\left(D_{L} r_{\mathrm{m}: \mathrm{N}}+A_{L}\right) \\
+k_{\mathrm{coag} 2} A_{S}\left(D_{S} r_{\mathrm{m}: \mathrm{N}}+A_{S}\right)-w_{l} \frac{\partial A_{L}}{\partial z}+M\left(A_{L}, z\right)(\mathrm{A} 11)
\end{gathered}
$$

where $F_{\text {dust }}$ is the deposition of dust at the ocean surface.

Processes controlling ligand concentration are described as ligand production by phytoplankton or release during remineralisation + release of free ligands by complex dissociation - ligands complexed with Fe(III)' - biological decomposition of free ligands + the physical term. An additional source of weak ligands is photolysis of strong complexes $k_{\text {phls }} f_{I} \mathrm{FeL}_{\mathrm{str}}$.

$$
\begin{gathered}
\frac{\partial}{\partial t} \mathrm{~L}_{\mathrm{str}}=\gamma_{l p} f_{Q} P+k_{\mathrm{flsd}} \mathrm{FeL}_{\mathrm{str}}-k_{\mathrm{fel}} \mathrm{Fe}(\mathrm{III})^{\prime} \\
\mathrm{L}_{\mathrm{str}}-\gamma_{l} f_{T} \mathrm{~L}_{\mathrm{str}}+M\left(\mathrm{~L}_{\mathrm{str}}, z\right)
\end{gathered}
$$

$$
\begin{gathered}
\frac{\partial}{\partial t} \mathrm{~L}_{\mathrm{we}}=\gamma_{l d} f_{T} D+k_{\mathrm{flwd}} \mathrm{FeL}_{\mathrm{we}}+k_{\mathrm{phls}} f_{I} \mathrm{FeL}_{\mathrm{str}}-k_{\mathrm{fel}} \mathrm{Fe}(\mathrm{III})^{\prime} \\
\mathrm{L}_{\mathrm{we}}-\gamma_{l} f_{T} \mathrm{~L}_{\mathrm{we}}+M\left(\mathrm{~L}_{\mathrm{we}}, z\right)
\end{gathered}
$$

where the production rate of strong ligands is regulated by the internal Fe:N-quota of phytoplankton:

$f_{Q}=\frac{Q_{\mathrm{Fe}}^{\max }-Q_{\mathrm{Fe}}}{Q_{\mathrm{Fe}}^{\max }}$ and a function of light intensity $f_{I}$ is introduced in all photochemical reactions:

$f_{I}=\frac{I(z)}{I_{\mathrm{ref}}}$

where $I(z)$ is the photosynthetically active radiation in the given vertical layer $z$.

The description of the concentration change of different $\mathrm{Fe}$ forms is more complex than in Weber et al. (2007) due to our introduction of more than one type of particles and ligands. The equations are:

$$
\begin{aligned}
& \frac{\partial}{\partial t} \mathrm{Fe}(\mathrm{III})^{\prime}=F_{\mathrm{Fe}(\mathrm{III})^{\prime}, \text { surf }}+ \\
& \quad\left(k_{\mathrm{ox} 1} \mathrm{O}_{2}+k_{\mathrm{Ox} 2} \mathrm{O}_{2}{ }^{-}+k_{\mathrm{Ox} 3} \mathrm{H}_{2} \mathrm{O}_{2}\right) \mathrm{Fe}(\mathrm{II})^{\prime} \\
& \quad+k_{c d} \mathrm{Fe}_{\mathrm{col}}+k_{\mathrm{flwd}} \mathrm{FeL}_{\mathrm{we}}+k_{\mathrm{flsd}} \mathrm{FeL}_{\mathrm{str}} \\
& \quad-\left(k_{\mathrm{fel}}\left(\mathrm{L}_{\mathrm{str}}+\mathrm{L}_{\mathrm{we}}\right)+k_{\mathrm{ph} 3} f_{I}+k_{\mathrm{red}} \mathrm{O}_{2}{ }^{-}+k_{\mathrm{col}}\right. \\
& \left.\quad+k_{\mathrm{sca}}\left(B+A_{S}+A_{L}+r_{\mathrm{m}: \mathrm{N}} D_{S}+r_{\mathrm{m}: \mathrm{N}} D_{L}\right)\right) \mathrm{Fe}(\mathrm{III})^{\prime} \\
& \quad+M\left(\mathrm{Fe}(\mathrm{III})^{\prime}, z\right)
\end{aligned}
$$

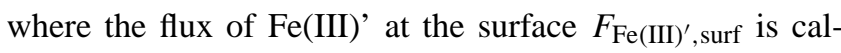
culated from modelled dust deposition by Mahowald et al. (2003) $F_{\text {dust }}$ with $3.5 \%$ Fe content in dust and $1 \%$ solubility.

$$
\begin{aligned}
& \frac{\partial}{\partial t} \mathrm{Fe}(\mathrm{II})^{\prime}=k_{\mathrm{red}} \mathrm{O}_{2}{ }^{-} \mathrm{Fe}(\mathrm{III})^{\prime}+f_{I} \\
& \quad\left(k_{\mathrm{ph} 3} \mathrm{Fe}(\mathrm{III})^{\prime}+k_{\mathrm{ph} 1 \mathrm{~s}} \mathrm{FeL}_{\mathrm{str}}+k_{\mathrm{ph} l \mathrm{w}} \mathrm{FeL}_{\mathrm{we}}\right. \\
& \left.\quad+k_{\mathrm{ph} 1} \mathrm{Fe}_{\mathrm{col}}\right)+k_{\mathrm{ph} 4}\left(\mathrm{Fe}_{\mathrm{dust}}+\mathrm{Fe}_{\mathrm{parts}}+\mathrm{Fe}_{\mathrm{partl}}\right) \\
& \quad-\left(k_{\mathrm{ox} 1} \mathrm{O}_{2}+k_{\mathrm{ox} 2} \mathrm{O}_{2}{ }^{-}+k_{\mathrm{ox} 3} \mathrm{H}_{2} \mathrm{O}_{2}\right) \mathrm{Fe}(\mathrm{II})^{\prime} \\
& \quad+M\left(\mathrm{Fe}(\mathrm{II})^{\prime}, z\right)
\end{aligned}
$$

where $\mathrm{Fe}_{\text {dust }}, \mathrm{Fe}_{\text {parts }}$, and $\mathrm{Fe}_{\text {partl }}$ are $\mathrm{Fe}$ adsorbed on surface of dust particles, small detritus and aggregates, and large detritus and aggregates, respectively.

$$
\begin{aligned}
& \frac{\partial}{\partial t} \mathrm{FeL}_{\mathrm{str}}=k_{\mathrm{fel}} \mathrm{Fe}(\mathrm{III})^{\prime} \mathrm{L}_{\mathrm{str}}-k_{\mathrm{flsd}} \mathrm{FeL}_{\mathrm{str}} \\
&-f_{I} k_{\mathrm{phls}} \mathrm{FeL}_{\mathrm{str}}-k_{\mathrm{upt}} \frac{\mathrm{FeL}_{\mathrm{str}}}{\mathrm{FeL}_{\mathrm{str}}+\mathrm{FeL}_{\mathrm{we}}}+M\left(\mathrm{FeL}_{\mathrm{str}}, z\right) \quad(\mathrm{A} 18) \\
& \frac{\partial}{\partial t} \mathrm{FeL}_{\mathrm{we}}=\gamma_{d} f_{T} D_{\mathrm{Fe}}+\gamma_{p} f_{T} P_{\mathrm{Fe}}+\gamma_{z b} f_{T} Z_{\mathrm{Fe}}+k_{\mathrm{fel}} \mathrm{Fe}(\mathrm{III})^{\prime} \mathrm{L}_{\mathrm{we}} \\
&-k_{\mathrm{flwd}} \mathrm{FeL}_{\mathrm{we}}-f_{I} k_{\mathrm{phlw}} \mathrm{FeL}_{\mathrm{we}} \\
&-k_{\text {upt }} \frac{\mathrm{FeL}_{\mathrm{we}}}{\mathrm{FeL}_{\mathrm{str}}+\mathrm{FeL}_{\mathrm{we}}}+M\left(\mathrm{FeL}_{\mathrm{we}}, z\right)
\end{aligned}
$$

The uptake rate $k_{\text {upt }}$ of $\mathrm{FeL}_{\text {str }}$ and $\mathrm{FeL}_{\text {we }}$ by phytoplankton is determined by:

$$
k_{\mathrm{upt}}=\min \left(\mu_{\mathrm{max}} \frac{\mathrm{FeL}_{\mathrm{str}}+\mathrm{FeL}_{\mathrm{we}}}{\left(\mathrm{FeL}_{\mathrm{str}}+\mathrm{FeL}_{\mathrm{we}}+K_{\mathrm{Fe}}\right)} P, \mu Q_{\mathrm{Fe}}^{\mathrm{ave}} P\right)
$$

Choosing the smaller one of the terms ensures a dependence of uptake on $\mathrm{Fe}_{\text {lig }}$ availability and a storage uptake is not considered. 


$$
\begin{aligned}
\frac{\partial}{\partial t} \mathrm{Fe}_{\mathrm{col}} & =k_{\mathrm{col}} \mathrm{Fe}(\mathrm{III})^{\prime}+k_{p d}\left(\mathrm{Fe}_{\mathrm{dust}}+\mathrm{Fe}_{\mathrm{parts}}+\mathrm{Fe}_{\mathrm{partl}}\right) \\
& -k_{a g}\left(B+A_{S}+A_{L}+r_{\mathrm{m}: \mathrm{N}} D_{S}+r_{\mathrm{m}: \mathrm{N}} D_{L}\right) \mathrm{Fe}_{\mathrm{col}} \\
& -k_{c d} \mathrm{Fe}_{\mathrm{col}}-f_{I} k_{\mathrm{ph} 1} \mathrm{Fe}_{\mathrm{col}}+M\left(\mathrm{Fe}_{\mathrm{col}}, z\right)
\end{aligned}
$$

$$
\begin{gathered}
\frac{\partial}{\partial t} \mathrm{Fe}_{\text {dust }}=\left(k_{\mathrm{sca}} \mathrm{Fe}(\mathrm{III})^{\prime}+k_{a g} \mathrm{Fe}_{\mathrm{col}}\right) B-\left(f_{I} k_{\mathrm{ph} 4}+k_{p d}\right) \mathrm{Fe}_{\text {dust }} \\
-k_{\mathrm{coag} 1} \mathrm{Fe}_{\text {dust }}\left(D_{S} r_{\mathrm{m}: \mathrm{N}}+A_{S}\right)-k_{\mathrm{coag} 4} \mathrm{Fe}_{\text {dust }}\left(D_{L} r_{\mathrm{m}: \mathrm{N}}+A_{L}\right) \\
-w_{d} \frac{\partial \mathrm{Fe}_{\text {dust }}}{\partial z}+M\left(\mathrm{Fe}_{\text {dust }}, z\right)
\end{gathered}
$$

$$
\begin{aligned}
& \frac{\partial}{\partial t} \mathrm{Fe}_{\mathrm{parts}}=\left(k_{\mathrm{sca}} \mathrm{Fe}(\mathrm{III})^{\prime}+k_{a g} \mathrm{Fe}_{\mathrm{col}}\right)\left(r_{\mathrm{m}: \mathrm{N}} D_{s}+A_{S}\right) \\
& \quad+k_{\mathrm{coag} 1} \mathrm{Fe}_{\text {dust }}\left(D_{S} r_{\mathrm{m}: \mathrm{N}}+A_{S}\right)-k_{\mathrm{coag} 3} \mathrm{Fe}_{\mathrm{parts}},\left(D_{L} r_{\mathrm{m}: \mathrm{N}}+A_{L}\right) \\
& \quad-k_{\mathrm{coag} 2} \mathrm{Fe}_{\mathrm{parts}}\left(D_{S} r_{\mathrm{m}: \mathrm{N}}+A_{S}\right)-\left(f_{I} k_{\mathrm{ph} 4}+k_{p d}\right) \mathrm{Fe}_{\mathrm{parts}} \\
& \quad-w_{s} \frac{\partial \mathrm{Fe}_{\mathrm{parts}}}{\partial z}+M\left(\mathrm{Fe}_{\mathrm{parts}}, z\right)
\end{aligned}
$$

$$
\begin{aligned}
& \frac{\partial}{\partial t} \mathrm{Fe}_{\mathrm{partl}}=\left(k_{\mathrm{sca}} \mathrm{Fe}(\mathrm{III})^{\prime}+k_{a g} \mathrm{Fe}_{\mathrm{col}}\right)\left(r_{\mathrm{m}: \mathrm{N}} D_{L}+A_{L}\right) \\
& \quad-k_{\mathrm{coag} 4} \mathrm{Fe}_{\mathrm{dust}}\left(D_{L} r_{\mathrm{m}: \mathrm{N}}+A_{L}\right)+k_{\mathrm{coag} 2} \mathrm{Fe}_{\mathrm{parts}}\left(D_{S} r_{\mathrm{m}: \mathrm{N}}+A_{S}\right) \\
& \quad+k_{\mathrm{coag} 3} \mathrm{Fe}_{\mathrm{parts}},\left(D_{L} r_{\mathrm{m}: \mathrm{N}}+A_{L}\right)-\left(f_{I} k_{\mathrm{ph} 4}+k_{p d}\right) \mathrm{Fe}_{\mathrm{partl}} \\
& \quad-w_{l} \frac{\partial \mathrm{Fe}_{\mathrm{partl}}}{\partial z}+M\left(\mathrm{Fe}_{\mathrm{partl}}, z\right)
\end{aligned}
$$

Finally, a variable Fe:N-quota is introduced in $P, Z$, and $D$ and evolution of the respective Fe concentrations $P_{\mathrm{Fe}}, Z_{\mathrm{Fe}}$ and $D_{\mathrm{Fe}}$ is described by:

$$
\begin{aligned}
\frac{\partial}{\partial t} P_{\mathrm{Fe}} & =k_{\mathrm{upt}}\left(\mathrm{FeL}_{\mathrm{str}}+\mathrm{FeL}_{\mathrm{we}}\right)-Q_{\mathrm{Fe}}\left(f_{G} Z+\gamma_{p^{2}} P^{2}\right) \\
& -\gamma_{p} f_{T} P_{\mathrm{Fe}}+M\left(P_{\mathrm{Fe}}, z\right)
\end{aligned}
$$

$$
\begin{aligned}
\frac{\partial}{\partial t} Z_{\mathrm{Fe}} & =Q_{\mathrm{Fe}} \gamma_{z a} f_{G} Z-\gamma_{z b} f_{T} Z_{\mathrm{Fe}}-Q_{Z \mathrm{Fe}} \gamma_{z^{2}} Z^{2} \\
& +M\left(Z_{\mathrm{Fe}}, z\right)
\end{aligned}
$$

$$
\begin{aligned}
& \frac{\partial}{\partial t} D_{\mathrm{SFe}}=Q_{\mathrm{Fe}} \gamma_{p^{2}} P^{2}+Q_{\mathrm{Fe}}\left(1-\gamma_{z a}\right) f_{G} Z \\
& \quad-k_{\mathrm{coag} 2} D_{\mathrm{SFe}}\left(D_{S} r_{\mathrm{m}: \mathrm{N}}+A_{S}\right)-k_{\mathrm{coag} 3} D_{\mathrm{SFe}}\left(D_{L} r_{\mathrm{m}: \mathrm{N}}+A_{L}\right) \\
& \quad-\gamma_{d} f_{T} D_{\mathrm{Fe}}+M\left(D_{\mathrm{Fe}}, z\right)
\end{aligned}
$$

$$
\begin{aligned}
& \frac{\partial}{\partial t} D_{\mathrm{LFe}}=Q_{Z \mathrm{Zee}} \gamma_{z^{2}} Z^{2}-\gamma_{d} f_{T} D_{\mathrm{LFe}} \\
& \quad+k_{\mathrm{coag} 2} D_{\mathrm{SFe}}\left(D_{S} r_{\mathrm{m}: \mathrm{N}}+A_{S}\right)+k_{\mathrm{coag} 3} D_{\mathrm{SFe}}\left(D_{L} r_{\mathrm{m}: \mathrm{N}}+A_{L}\right) \\
& \quad-\gamma_{d} f_{T} D_{\mathrm{LFe}}+M\left(D_{\mathrm{LFe}}, z\right)
\end{aligned}
$$

Table B1. Sensitivity studies with respect to ecosystem parameters. Relative change is calculated as the ratio of the parameter value in the sensitivity study to the one in the standard model run.

\begin{tabular}{lrrr}
\hline $\begin{array}{l}\text { parameter } \\
\text { symbol }\end{array}$ & $\begin{array}{r}\text { relative change } \\
\text { of parameter } \\
\text { value }\end{array}$ & $\begin{array}{r}\text { relative change } \\
\text { of primary } \\
\text { production }\end{array}$ & $\begin{array}{r}\text { relative } \\
\text { change of } \\
\text { export }(100 \mathrm{~m})\end{array}$ \\
\hline$\mu_{\max }$ & 0.8 & 0.99 & 0.89 \\
$K_{\mathrm{N}}$ & 1.2 & 0.99 & 1.03 \\
& 0.5 & 0.98 & 1.0 \\
$\alpha$ & 2.0 & 0.99 & 0.95 \\
& 0.6 & 0.96 & 0.92 \\
$\gamma_{p}$ & 0.8 & 0.98 & 0.96 \\
& 0.5 & 0.74 & 1.40 \\
$g_{\max }$ & 2.0 & 1.25 & 0.38 \\
& 0.5 & 1.00 & 0.98 \\
$\gamma_{p}{ }^{2}$ & 1.5 & 0.98 & 0.98 \\
& 0.5 & 0.99 & 0.98 \\
$\gamma_{z}{ }^{2}$ & 2.0 & 0.99 & 0.98 \\
$\gamma_{z a}$ & 0.5 & 0.94 & 1.0 \\
& 2.0 & 0.94 & 1.09 \\
$\gamma_{d}$ & 0.54 & 1.21 & 0.82 \\
& 1.07 & 0.97 & 1.0 \\
\hline
\end{tabular}

Table B2. Sensitivity studies with respect to iron solubility and content in dust particles

\begin{tabular}{lcc}
\hline study number & iron content $(\%)$ & surface DFe (nM) \\
\hline 1 & 3 & $0.15-0.49$ \\
2 & 6 & $0.17-0.72$ \\
3 & 12 & $0.23-1.33$ \\
4 & 24 & $0.32-2.6$ \\
\hline
\end{tabular}

\section{Appendix B}

\section{Sensitivity studies}

Primary and export production are not very sensitive to most parameters, except to the exudation rate of phytoplankton $\left(\gamma_{p}\right)$ (Table B1). This exudation rate determines the flux of the shortcut from phytoplankton to nutrients. Decreasing $\gamma_{p}$ to half of the standard value leads to a decrease of primary production to $74 \%$, because less nutrients are available for phytoplankton growth. This result is closer to the estimated primary production from MODIS data. However, the ratio of export/primary production rises to $27 \%$ which is higher than most typical values estimated for open-ocean (De La Rocha and Passow, 2007), indicating too slow transformation of biomass into nutrient in surface waters. Therefore, we kept applying the parameter values from Schartau and Oschlies (2003a,b) optimised for the North Atlantic. 
Measured Fe content in dust varies from 3 to $7.6 \%$ (Wedepohl, 1995; Duce and Tindale, 1991; Spokes and Jickells, 1996; Desboeufs et al., 2001). We only varied iron content in the sensitivity study (Table B2) and multiplied it with $1 \%$ iron solubility which is close to the most reported mean iron solubility of Saharan dust (Baker et al., 2006a,b; Baker and Jickells, 2006; Spokes and Jickells, 1996). DFe surface concentration increases in the sensitivity study exponentially with increasing iron content. The modelled DFe surface concentration from the sensitivity studies No. 3 and 4 is much too high compared to the observations near Cape Verde Islands, which ranges between 0.15 to $0.52 \mathrm{nmol} \mathrm{L}^{-1}$ (see Sect. 3.4.2 Modelled DFe concentration). In the other two studies (No. 1 and 2), surface DFe is in the similar range as the observations and biology is quite insensitive to different Fe input: the averaged primary production is changed only about $1 \%$. This result supports our choice of $1 \%$ solubility and $3.5 \%$ iron content which is between the parameter values in the sensitivity studies No. 1 and 2. TENATSO is close to the dust source region and dry deposition is predominant which also makes it reasonable to take a smaller solubility or a smaller product of solubility and iron content for our model calculation.

Acknowledgements. This work is a contribution to the project SOPRAN (Surface Ocean Processes in the ANtropocene), which is funded by the German Federal Ministry of Education and Research (BMBF project 03F0462C). We sincerely thank M. Rijkenberg and I. Peeken for kindly providing unpublished data, L. Cotrim da Cunha, I. Hense, and J. Wu for providing data, and H. Burchard and K. Bolding for technical support.

Edited by: K. Hunter

\section{References}

Amon, R. and Benner, R.: Rapid cycling of high-molecular-weight dissolved organic matter in the ocean, Nature, 369, 549-552, 1994.

Armstrong, R., Lee, C., Hedges, J., Honjo, S., and Wakeham, S.: A new, mechanistic model for organic carbon fluxes in the ocean based on the quantitative association of POC with ballast minerals, Deep-Sea Res. II, 49, 219-236, 2002.

Asper, V. and Smith, W. J.: Abundance, distribution and sinking rates of aggregates in the Ross Sea, Antarctica, Deep-Sea Res. I, 50, 131-150, doi:10.1016/S0967-0637(02)00146-2, 2003.

Asper, V., Deuser, W., Knauer, G., and Lohrenz, S.: Rapid coupling of sinking particle fluxes between surface and deep ocean waters, Nature, 357, 670-672, 1992.

Aumont, O., Maier-Reimer, E., Blain, S., and Monfray, P.: An ecosystem model of the global ocean including $\mathrm{Fe}, \mathrm{Si}, \mathrm{P}$ colimitations, Global Biogeochem. Cy., 17, 1060, doi:10.1029/ 2001GB001745, 2003.

Bacon, M. P. and Anderson, R. F.: Distribution of thorium isotopes between dissolved and particulate forms in the deep sea, J. Geophys. Res., 87(C3), 2045-2056, doi:10.1029/JC087iC03p02045, 1982.
Baker, A., Jickells, T., Biswas, K., Weston, K., and French, M.: Nutrients in atmospheric aerosol particles along the Atlantic Meridional Transect, Deep Sea Res. II, 53, 1706-1719, doi: 10.1016/j.dsr2.2006.05.012, 2006a.

Baker, A., Jickells, T., Witt, M., and Linge, K.: Trends in the solubility of iron, aluminium, manganese and phosphorus in aerosol collected over the Atlantic Ocean, Mar. Chem., 98, 4358, 2006b.

Baker, A. R. and Jickells, T. D.: Mineral particle size as a control on aerosol iron solubility, Geophys. Res. Lett., 33, L17608, doi: 10.1029/2006GL026557, 2006.

Balistieri, L., Brewer, P., and Murray, J.: Scavenging residence times of trace metals and surface chemistry of sinking particles in the deep ocean, Deep Sea Res., 28A, 101-121, 1981.

Barbeau, K. and Moffett, J.: Laboratory and field studies of colloidal iron oxide dissolution as mediated by phagotrophy and photolysis, Limnol. Oceanogr., 45(4), 827-835, 2000.

Barbeau, K., Rue, E., Bruland, K., and Butler, A.: Photochemical cycling of iron in the surface ocean mediated by microbial iron(III)-binding ligands, Nature, 413, 409-413, 2001.

Barbeau, K., Rue, E., Trick, C., Bruland, K., and Butler, A.: Photochemical reactivity of siderophores produced by marine heterotrophic bacteria and cyanobacteria based on characteristic Fe(III) binding groups, Limnol. Oceanogr., 48, 1069-1078, 2003.

Behrenfeld, M. and Falkowski, P.: Photosynthetic rates derived from satellite-based chlorophyll concentration, Limnol. Oceanogr., 42, 1-20, 1997.

Bergquist, B., Wu, J., and Boyle, E.: Variability in oceanic dissolved iron is dominated by the colloidal fraction, Geochim. Cosmochim. Ac., 71, 2960-2974, doi:10.1016/j.gca.2007.03.013, 2007.

Bory, A., Jeandel, C., Leblond, N., Vangriesheim, A., Khripounoff, A., Beaufort, L., Rabouille, C., Nicolas, E., Tachikawa, K., Etcheber, H., and Buat-Ménard, P.: Downward particle fluxes within different productivity regimes off the Mauritanian upwelling zone (EUMELI program), Deep Sea Res. I, 48, 22512282, 2001.

Boyd, P. W., Jickells, T., Law, C. S., Blain, S., Boyle, E. A., Buesseler, K. O., Coale, K. H., Cullen, J. J., de Baar, H. J. W., Follows, M., Harvey, M., Lancelot, C., Levasseur, M., Owens, N. P. J., Pollard, R., Rivkin, R. B., Sarmiento, J., Schoemann, V., Smetacek, V., Takeda, S., Tsuda, A., Turner, S., and Watson, A. J.: Mesoscale Iron Enrichment Experiments 1993-2005: Synthesis and Future Directions, Science, 315, 612-617, 2007.

Boye, M., Van den Berg, C., De Jong, J., Leach, H., Croot, P., and De Baar, H.: Organic complexation of iron in the Southern Ocean, Deep-Sea Res. I, 48, 1477-1497, 2001.

Boye, M., Aldrich, A., van den Berg, C., de Jong, J., Nirmaier, H., Veldhuis, M., Timmermans, K., and de Baar, H.: The chemical speciation of iron in the north-east Atlantic Ocean, Deep-Sea Res. I, 53, 667-683, 2006.

Broecker, W. S. and Peng, T.-H.: Tracers in the sea, in: Tracers in the sea, Eldigio Press Lamont Doherty Geological Observatory, 2-5, 1982.

Burchard, H. and Umlauf, L.: Observations and numerical modelling of mixed-layer turbulence: Do they represent the same statistical quantities?, Deep Sea Res. II, 52, 1069-1074, doi: 10.1016/j.dsr2.2005.03.002, 2005. 
Burchard, H., Delersnijder, E., and Meister, A.: Application of modified Patankar schemes to stiff biogeochemical models for the water column, Ocean Dynam., 55, 326-337, 2005.

Burd, A. and Jackson, G.: Particle Aggregation, Annu. Rev. Mar. Sci., 1, 65-90, doi:10.1146/annurev.marine.010908.163904, 2009.

Carpenter, E. J., Subramaniam, A., and Capone, D. G.: Biomass and primary productivity of the cyanobacterium Trichodesmium spp. in the tropical N Atlantic ocean, Deep Sea Res. I, 51, 173-203, 2004.

Chiapello, I., Bergametti, G., Chatenet, B., Bousquet, P., Dulac, F., and Soares, E. S.: Origins of African dust transported over the northeastern tropical Atlantic, J. Geophys. Res., 102(D12), 13701-13709, 1997.

Cloern, J. E., Grenz, C., and Vidergar-Lucas, L.: An empirical model of the phytoplankton chlorophyll : carbon ratio-the conversion factor between productivity and growth rate, Limnol. Oceanogr., 40(7), 1313-1321, 1995.

Cullen, J., Bergquist, B., and Moffett, J.: Thermodynamic characterization of the partitioning of iron between soluble and colloidal species in the Atlantic Ocean, Mar. Chem., 98, 295-303, 2006.

De Boyer Montegut, C. Madec, G., Fischer, A., Lazar, A., and Iudicone, D.: Mixed layer depth over the global ocean: An examination of profile data and a profile-based climatology, J. Geophys. Res. C. Oceans, 109, C12003, doi:10.1029/2004JC002378, 2004.

De La Rocha, C. and Passow, U.: Factors influencing the sinking of POC and the efficiency of the biological carbon pump, Deep Sea Res. II, 54, 639-658, doi:10.1016/j.dsr2.2007.01.004, 2007.

Desboeufs, K. V., Losno, R., and Colin, J. L.: Factors influencing aerosol solubility during cloud processes, Atmos. Environ., 35, 3529-3537, 2001.

Duce, R. and Tindale, N.: Atmospheric transport of iron and its deposition in the ocean, Limnol. Oceanogr., 36, 1715-1726, 1991.

Emery, K. and Honjo, S.: Surface suspended matter off western Africa: relations of organic matter, skeletal debris and detrital minerals, Sedimentology, 26, 775-794, 1979.

Falkowski, P.: Evolution of the nitrogen cycle and its influence on the biological sequestration of $\mathrm{CO}_{2}$ in the ocean, Nature, 387, 272-275, 1997.

Fischer, G; Ratmeyer, V. and Wefer, G.: Organic carbon fluxes in the Atlantic and the Southern Ocean: relationship to primary production compiled from satellite radiometer data, Deep-Sea Res. II, 47, 1961-1997, doi:10.1016/S0967-0645(00)00013-8, 2000.

Francois, R., Honjo, S., Krishfield, R., and Manganini, S.: Factors controlling the flux of organic carbon to the bathypelagic zone of the ocean, Global Biogeochem. Cy., 16, 1087, doi:10.1029/ 2001GB001722, 2002.

Gerringa, L., Veldhuis, M., Timmermans, K., Sarthou, G., and de Baar, H.: Co-variance of dissolved Fe-binding ligands with phytoplankton characteristics in the Canary Basin, Mar. Chem., 102, 276-290, 2006.

Gerringa, L., Blain, S., Laan, P., Sarthou, G., Veldhuis, M., Brussaard, C., Viollier, E., and Timmermans, K.: Fe-binding dissolved organic ligands near the Kerguelen Archipelago in the Southern Ocean (Indian sector), Deep Sea Res. II, 55, 606-621, 2008.

Gledhill, M. and van den Berg, C.: Determination of complexation of iron(III) with natural organic complexing ligands in seawater using cathodic stripping voltammetry, Mar. Chem., 47, 41-54, 1994.

Granger, J. and Price, N. M.: The importance of siderophores in iron nutrition of heterotrophic marine bacteria, Limnol. Oceanogr., 44, 541-555, 1999.

Graziano, L., Geider, R., Li, W., and Olaizola, M.: Nitrogen limitation of North Atlantic phytoplankton: analysis of physiological condition in nutrient enrichment experiments, Aquat. Microb. Ecol., 11, 53-64, 1996.

Gruber, N., Frenzel, H., Doney, S., Marchesiello, P., McWilliams, J., Moisan, J., Oram, J., Plattner, G.-K., and Stolzenbach, K.: Eddy-resolving simulation of plankton ecosystem dynamics in the California Current System, Deep Sea Res. I, 53, 1483-1516, doi:10.1016/j.dsr.2006.06.005, 2006.

Guieu, C., Bozec, Y., Blain, S., Ridame, C., Sarthou, G., and Leblond, N.: Impact of high Saharan dust inputs on dissolved iron concentrations in the Mediterranean Sea, Geophys. Res. Lett., 29, 17-1-17-4, doi:10.1029/2001GL014454, 2002.

Hamm, C.: Interactive aggregation and sedimentation of diatoms and clay-sized lithogenic material, Limnol. Oceanogr., 47, 17901795, 2002.

Heinold, B., Helmert, J., Hellmuth, O., Wolke, R., Ansmann, A., Marticorena, B., Laurent, B., and Tegen, I.: Regional modeling of Saharan dust events using LM-MUSCAT: Model description and case studies, J. Geophys. Res., 112, D11204, doi:10.1029/ 2006JD007443, 2007.

Honjo, S., Manganini, S., and Poppe, L.: Sedimentation of lithogenic particles in the deep ocean, Mar. Geol., 50, 199-220, 1982.

Hudson, R., Covault, D., and Morel, F.: Investigations of iron coordination and redox reactions in seawater using ${ }^{59} \mathrm{Fe}$ radiometry and ion-pair solvent extraction of amphiphilic iron complexes, Mar. Chem., 38, 209-235, 1992.

Hunter, K. A. and Boyd, P. W.: Iron-binding ligands and their role in the ocean biogeochemistry of iron, Environ. Chem., 4, 221-232, 2007.

Hutchins, D., Witter, A., Butler, A., and Luther III, G.: Competition among marine phytoplankton for different chelated iron species, Nature, 400, 858-861, 1999.

Hutchins, D., Hare, C., Weaver, R., Zhang, Y., Firme, G., DiTullio, G., Alm, M., Riseman, S., Maucher, J., Geesey, M., Trick, C., Smith, G., Rue, E., Conn, J., and Bruland, K.: Phytoplankton iron limitation in the Humboldt Current and Peru Upwelling, Limnol. Oceanogr., 47, 997-1011, 2002.

Jackson, G. A. and Burd, A. B.: Aggregation in the Marine Environment, Environ. Sci. Technol., 32, 2805-2814, doi:10.1021/ es980251w, 1998.

Jickells, T. D., An, Z. S., Andersen, K. K., Baker, A. R., Bergametti, G., Brooks, N., Cao, J. J., Boyd, P. W., Duce, R. A., Hunter, K. A., Kawahata, H., Kubilay, N., laRoche, J., Liss, P. S., Mahowald, N., Prospero, J. M., Ridgwell, A. J., Tegen, I., and Torres, R.: Global Iron Connections Between Desert Dust, Ocean Biogeochemistry, and Climate, Science, 308, 67-71, 2005.

Johnson, K., Coale, K., Elrod, V., and Tindale, N.: Iron photochemistry in seawater from the equatorial Pacific, Mar. Chem., 46, 319-334, 1994.

Johnson, K., Gordon, R., and Coale, K.: What controls dissolved iron concentrations in the world ocean?, Mar. Chem., 57, 137- 
$161,1997$.

Klaas, C. and Archer, D.: Association of sinking organic matter with various types of mineral ballast in the deep sea: Implications for the rain ratio, Global Biogeochem. Cy., 16, 1116, doi: 10.1029/2001GB001765, 2002.

Kondo, Y., Takeda, S., Nishioka, J., Obata, H., Furuya, K., Johnson, W. K., and Wong, C. S.: Organic iron (III) complexing ligands during an iron enrichment experiment in the western subarctic North Pacific, Geophys. Res. Lett., 35, L12601, doi: 10.1029/2008GL033354, 2008.

Kriest, I.: Different parameterizations of marine snow in a 1Dmodel and their influence on representation of marine snow, nitrogen budget and sedimentation, Deep-Sea Res. I, 49, 2133 2162, doi:10.1016/S0967-0637(02)00127-9, 2002.

Laglera, L. M. and van den Berg, C. M. G.: Evidence for geochemical control of iron by humic substances in seawater, Limnol. Oceanogr., 54(2), 610-619, 2009.

Lewis, B., Luther, G. I., Lane, H., and Church, T.: Determination of metal-organic complexation in natural waters by SWASV with pseudopolarograms, Electroanalysis, 7, 166-177, 1995.

Lutz, M., Dunbar, R., and Caldeira, K.: Regional variability in the vertical flux of particulate organic carbon in the ocean interior, Global Biogeochem. Cy., 16, 1037, doi:10.1029/ 2000GB001383, 2002.

Macrellis, H., Trick, C., Rue, E., Smith, G., and Bruland, K.: Collection and detection of natural iron-binding ligands from seawater, Mar. Chem., 76, 175-187, 2001.

Mahowald, N., Luo, C., Del Corral, J., and Zender, C.: Interannual variability in atmospheric mineral aerosols from a 22-year model simulation and observational data, J. Geophys. Res.-Atmos., 108, 4352, doi:10.1029/2002JD002821, 2003.

Maldonado, M. and Price, N.: Utilization of iron bound to strong organic ligands by plankton communities in the subarctic North Pacific, Deep Sea Res. II, 46, 2447-2473, 1999.

Martin, J., Knauer, G., Karl, D., and Broenkow, W.: VERTEX: Carbon cycling in the Northeast Pacific, Deep-Sea Res. A, 34, $267-$ 285, 1987.

Martinez, J. and Haygood, M.: Identification of a natural desferrioxamine siderophore produced by a marine bacterium, Limnol. Oceanogr. Suppl., 420-424, 2001.

Martinez, J., Carter-Franklin, J., Mann, E., Martin, J., Haygood, M., and Butler, A.: Structure and membrane affinity of a suite of amphiphilic siderophores produced by a marine bacterium, P. Natl. Acad. Sci. USA, 100, 3754-3759, doi:10.1073/pnas. 0637444100, 2003.

Martinez, J. S., Zhang, G. P., Holt, P. D., Jung, H.-T., Carrano, C. J., Haygood, M. G., and Butler, A.: Self-assembling amphiphilic siderophores from marine bacteria, Science, 287, 1245-1247, doi:10.1126/science.287.5456.1245, 2000.

McCave, I.: Size spectra and aggregation of suspended particles in the deep ocean, Deep-Sea Res. A, 31, 329-352, 1984.

Micinski, E., Ball, L. A., and Zafiriou, O. C.: Photochemical Oxygen Activation: Superoxide Radical Detection and Production Rates in the Eastern Caribbean, J. Geophys. Res., 98(C2), 22992306, doi:10.1029/92JC02766, 1993.

Millero, F. and Sotolongo, S.: The oxidation of $\mathrm{Fe}(\mathrm{II})$ with $\mathrm{H}_{2} \mathrm{O}_{2}$ in seawater, Geochim. Cosmochim. Ac., 53, 1867-1873, 1989.

Mills, M., Ridame, C., Davey, M., La Roche, J., and Geider, R.: Iron and phosphorus co-limit nitrogen fixation in the eastern tropical North Atlantic, Nature, 429, 292-294, 2004.

Moffett, J. W.: Temporal and spatial variability of copper complexation by strong chelators in the Sargasso Sea, Deep Sea Res. I, 42, 1273-1295, 1995.

Morel, A., Antoine, D., Babin, M., and Dandonneau, Y.: Measured and modeled primary production in the northeast Atlantic (EUMELI JGOFS program): the impact of natural variations in photosynthetic parameters on model predictive skill, Deep Sea Res. I, 43, 1273-1304, 1996.

Parekh, P., Follows, M., and Boyle, E.: Modelling the global ocean iron cycle, Global Biogeochem. Cy., 18, GB1002, doi: 1029/2003GB002061, 2004.

Passow, U.: Switching perspectives: Do mineral fluxes determine particulate organic carbon fluxes or vice versa?, Geochem. Geophy. Geosy., 5, Q04002, doi:10.1029/2003GC000670, 2004.

Passow, U. and De la Rocha, C.: Accumulation of mineral ballast on organic aggregates, Global Biogeochem. Cy., 20, GB4S23, doi:10.1029/2005GB002579, 2006.

Powell, R. and Wilson-Finelli, A.: Photochemical degradation of organic iron complexing ligands in seawater, Aquat. Sci., 65, 367-374, 2003.

Ratmeyer, V., Fischer, G., and Wefer, G.: Lithogenic particle fluxes and grain size distributions in the deep ocean off Northwest Africa: Implications for seasonal changes of aeolian dust input and downward transport, Deep-Sea Res. I, 46, 1289-1337, doi: 10.1016/S0967-0637(99)00008-4, 1999.

Reid, R., Live, D., Faulkner, D., and Butler, A.: A siderophore from a marine bacterium with an exceptional ferric ion affinity constant, Nature, 366, 455-458, 1993.

Rijkenberg, M., Powell, C., Dall'Osto, M., Nielsdottir, M., Patey, M., Hill, P., Baker, A., Jickells, T., Harrison, R., and Achterberg, E.: Changes in iron speciation following a Saharan dust event in the tropical North Atlantic Ocean, Mar. Chem., 110, 56-67, doi:10.1016/j.marchem.2008.02.006, 2008.

Rose, A. and Waite, T.: Predicting iron speciation in coastal waters from the kinetics of sunlight-mediated iron redox cycling, Aquat. Sci., 65, 375-383, 2003a.

Rose, A. and Waite, T.: Kinetics of hydrolysis and precipitation of ferric iron in seawater, Environ. Sci. Technol., 37, 3897-3903, 2003 b.

Rose, A. and Waite, T.: Kinetics of iron complexation by dissolved natural organic matter in coastal waters, Mar. Chem., 84, 85-103, $2003 c$.

Rue, E. and Bruland, K.: Complexation of iron(III) by natural organic ligands in the Central North Pacific as determined by a new competitive ligand equilibration/adsorptive cathodic stripping voltammetric method, Mar. Chem., 50, 117-138, 1995.

Rue, E. and Bruland, K.: The role of organic complexation on ambient iron chemistry in the equatorial Pacific Ocean and the response of a mesoscale iron addition experiment, Limnol. Oceanogr., 42, 901-910, 1997.

Ruiz, J., Prieto, L., and Ortegón, F.: Diatom aggregate formation and fluxes: a modeling analysis under different size-resolution schemes and with empirically determined aggregation kernels, Deep Sea Res. I, 49, 495-515, 2002.

Sarthou, G., Baker, A., Blain, S., Achterberg, E., Boye, M., Bowie, A., Croot, P., Laan, P., De Baar, H., Jickells, T., and Worsfold, P.: Atmospheric iron deposition and sea-surface dissolved iron concentrations in the eastern Atlantic Ocean, Deep-Sea Res. I, 
50, 1339-1352, 2003.

Sarthou, G., Baker, A. R., Kramer, J., Laan, P., Laës, A., Ussher, S., Achterberg, E. P., de Baar, H. J., Timmermans, K. R., and Blain, S.: Influence of atmospheric inputs on the iron distribution in the subtropical North-East Atlantic Ocean, Mar. Chem., 104, 186202, doi:10.1016/j.marchem.2006.11.004, 2007.

Schartau, M. and Oschlies, A.: Simultaneous data-based optimization of a 1D-ecosystem model at three locations in the North Atlantic: Part I. Method and parameter estimates, J. Mar. Res., 61, 765-793, 2003a.

Schartau, M. and Oschlies, A.: Simultaneous data-based optimization of a 1D-ecosystem model at three locations in the North Atlantic: Part II. Standing stocks and nitrogen fluxes, J. Mar. Res., 61, 795-821, 2003b.

Schlosser, C. and Croot, P. L.: Controls on seawater Fe(III) solubility in the Mauritanian upwelling zone, Geophys. Res. Lett., 36, L18606, doi:10.1029/2009GL038963, 2009.

Smayda, T.: The suspension and sinking of phytoplankton in the sea (RV), Ocean. Mar. Biol., 8, 353-414, 1970.

Spokes, L. and Jickells, T.: Factors controlling the solubility of aerosol trace metals in the atmosphere and on mixing into seawater, Aquat. Geochem., 1, 355-374, 1996.

Steigenberger, S. and Croot, P.: Identifying the processes controlling the distribution of $\mathrm{H}_{2} \mathrm{O}_{2}$ in surface waters along a meridional transect in the eastern Atlantic, Geophys. Res. Lett., 35, L03616, doi:10.1029/2007GL032555, 2008.

Sunda, W. and Huntsman, S.: Iron uptake and growth limitation in oceanic and coastal phytoplankton, Mar. Chem., 50, 189-206, 1995.

Tagliabue, A., Bopp, L., Aumont, O., and Arrigo, K. R.: Influence of light and temperature on the marine iron cycle: From theoretical to global modeling, Global Biogeochem. Cy., 23, GB2017, doi:10.1029/2008GB003214, 2009.

Tovar-Sanchez, A., Sañudo-Wilhelmy, S. A., Garcia-Vargas, M., Weaver, R. S., Popels, L. C., and Hutchins, D. A.: A trace metal clean reagent to remove surface-bound iron from marine phytoplankton, Mar. Chem., 82, 91-99, doi:10.1016/S0304-4203(03) 00054-9, 2003.

Trick, C.: Hydroxamate-siderophore production and utilization by marine eubacteria, Current Microbiology, 18, 375-378, 1989.

Tyrrell, T., Maranon, E., Poulton, A. J., Bowie, A. R., Harbour, D. S., and Woodward, E. M. S.: Large-scale latitudinal distribution of Trichodesmium spp. in the Atlantic Ocean, J. Plankton Res., 25, 405-416, 2003.

Umlauf, L. and Burchard, H.: Second-order turbulence closure models for geophysical boundary layers. A review of recent work, Cont. Shelf Res., 25, 795-827, 2005.

Uppala, S., Kå llberg, P., Simmons, A., Andrae, U., da Costa Bechtold, V., Fiorino, M., Gibson, J., Haseler, J., Hernandez, A., Kelly, G., Li, X., Onogi, K., Saarinen, S., Sokka, N., Allan, R., Andersson, E., Arpe, K., Balmaseda, M., Beljaars, A., van de Berg, L., Bidlot, J., Bormann, N., Caires, S., Chevallier, F., Dethof, A., Dragosavac, M., Fisher, M., Fuentes, M., Hagemann, S., Hólm, E., Hoskins, B., Isaksen, L., Janssen, P., Jenne, R., McNally, A., Mahfouf, J.-F., Morcrette, J.-J., Rayner, N., Saunders, R., Simon, P., Sterl, A., Trenberth, K., Untch, A., Vasiljevic, D., Viterbo, P., and Woollen, J.: The ERA-40 re-analysis, Q. J. Roy. Meteorol. Soc., 131, 2961-3012, doi:10.1256/qj.04.176, 2005. van den Berg, C.: Evidence for organic complexation of iron in seawater, Mar. Chem., 50, 139-157, 1995.

van der Loeff, M. R., Helmers, E., and Kattner, G.: Continuous transects of cadmium, copper, and aluminium in surface waters of the Atlantic Ocean, $50^{\circ} \mathrm{N}$ to $50^{\circ} \mathrm{S}$ : correspondence and contrast with nutrient-like behaviour, Geochim. Cosmochim. Ac., 61, 4761, 1997.

Voelker, B. and Sedlak, D.: Iron reduction by photoproduced superoxide in seawater, Mar. Chem., 50, 93-102, 1995.

Wang, W.-X. and Dei, R.: Biological uptake and assimilation of iron by marine plankton: Influences of macronutrients, Mar. Chem., 74, 213-226, 2001.

Weber, L., Völker, C., Schartau, M., and Wolf-Gladrow, D.: Modeling the speciation and biogeochemistry of iron at the Bermuda Atlantic Time-series Study site, Global Biogeochem. Cy., 19, GB1019, doi:10.1029/2004GB002340, 2005.

Weber, L., Völker, C., Oschlies, A., and Burchard, H.: Iron profiles and speciation of the upper water column at the Bermuda Atlantic Time-series Study site: a model based sensitivity study, Biogeosciences, 4, 689-706, 2007, http://www.biogeosciences.net/4/689/2007/.

Wedepohl, K. H.: The composition of the continental crust, Geochim. Cosmochim. Ac., 59, 1217-1232, doi:10.1016/ 0016-7037(95)00038-2, 1995.

Wells, M. and Goldberg, E.: Colloid aggregation in seawater, Mar. Chem., 41, 353-358, 1993.

Wen, L.-S., Santschi, P., and Tang, D.: Interactions between radioactively labeled colloids and natural particles: Evidence for colloidal pumping, Geochim. Cosmochim. Ac., 61, 2867-2878, 1997.

Wilhelm, S. and Trick, C.: Iron-limited growth of cyanobacteria: Multiple siderophore production is a common response, Limnol Oceanogr., 39, 1979-1984, 1994.

Wilhelm, S., Maxwell, D., and Trick, C.: Growth, iron requirements, and siderophore production in iron-limited Synechococcus PCC 7002, Limnol. Oceanogr., 41, 89-97, 1996.

Witter, A. and Luther III, G.: Variation in Fe-organic complexation with depth in the northwestern Atlantic Ocean as determined using a kinetic approach, Mar. Chem., 62, 241-258, 1998.

Witter, A., Lewis, B., and Luther, G. I.: Iron speciation in the Arabian Sea, Deep-Sea Res. II, 47, 1517-1539, doi:10.1016/ S0967-0645(99)00152-6, 2000.

$\mathrm{Wu}, \mathrm{J}$. and Boyle, E.: Iron in the Sargasso Sea: Implications for the processes controlling dissolved $\mathrm{Fe}$ distribution in the ocean, Global Biogeochem. Cy., 16, 1086, doi:10.1029/ 2001GB001453, 2002.

Wu, J., Boyle, E., Sunda, W., and Wen, L.-S.: Soluble and colloidal iron in the oligotrophic North Atlantic and North Pacific, Science, 293, 847-849, 2001.

Zielinski, O., Llinás, O., Oschlies, A., and Reuter, R.: Underwater light field and its effect on a one-dimensional ecosystem model at station ESTOC, north of the Canary Islands, Deep Sea Res. II, 49, 3529-3542, 2002. 